Published in final edited form as:

Mitochondrion. 2017 March ; 33: 84-101. doi:10.1016/j.mito.2016.08.017.

\title{
The mitochondrial $\mathrm{BK}_{\mathrm{Ca}}$ channel cardiac interactome reveals $\mathrm{BK}_{\mathrm{Ca}}$ association with the mitochondrial import receptor subunit Tom22, and the adenine nucleotide translocator
}

\author{
Jin Zhang ${ }^{\mathrm{a}, \mathrm{c}}$, Min Li ${ }^{\mathrm{a}}$, Zhu Zhang ${ }^{\mathrm{a}}$, Ronhui Zhu ${ }^{\mathrm{a}}$, Riccardo Olcese ${ }^{\mathrm{a}, \mathrm{b}, \mathrm{d}, \mathrm{e},{ }^{,}, \text {Enrico }}$

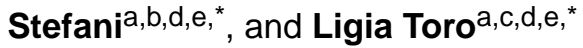 \\ aDepartment of Anesthesiology, Division of Molecular Medicine, University of California, Los \\ Angeles, Los Angeles, CA, USA. \\ ${ }^{b}$ Department of Physiology, University of California, Los Angeles, Los Angeles, CA, USA. \\ 'Department of Molecular \& Medical Pharmacology, University of California, Los Angeles, Los \\ Angeles, CA, USA. \\ dBrain Research Institute, University of California, Los Angeles, Los Angeles, CA, USA. \\ eCardiovascular Research Laboratory, University of California, Los Angeles, Los Angeles, CA, \\ USA.
}

\begin{abstract}
Mitochondrial $\mathrm{BK}_{\mathrm{Ca}}$ channel, mitoBK $\mathrm{Ca}_{\mathrm{Ca}}$, regulates mitochondria function in the heart but information on its protein partnerships in cardiac mitochondria is missing. A directed proteomic approach discovered the novel interaction of $\mathrm{BK}_{\mathrm{Ca}}$ with Tom22, a component of the mitochondrion outer membrane import system, and the adenine nucleotide translocator (ANT). The expressed protein partners co-immunoprecipitated and co-segregated into mitochondrial fractions in HEK293T cells. The $\mathrm{BK}_{\mathrm{Ca}} 50$ amino acid splice insert, $\mathrm{DEC}$, facilitated $\mathrm{BK}_{\mathrm{Ca}}$ interaction with ANT. Further, $\mathrm{BK}_{\mathrm{Ca}}$ transmembrane domain was required for the association with both Tom 22 and ANT. The results serve as a working framework to understand mitoBK $\mathrm{Ca}$ import and functional relationships.
\end{abstract}

\section{Keywords}

Proteomics; BK channel; MaxiK channel; potassium ion channel; mitochondria; heart; Tom22; adenine nucleotide translocator; macromolecular complex

\footnotetext{
Address correspondence to: Dr. Ligia Toro, Department of Anesthesiology, UCLA School of Medicine, BH-509A CHS, Box 957115, Los Angeles, CA 90095-7115, Phone: 1 (310) 709 5204, FAX: 1 (310) 825 5379, 1toro@ucla.edu.

Co-senior authors

Publisher's Disclaimer: This is a PDF file of an unedited manuscript that has been accepted for publication. As a service to our customers we are providing this early version of the manuscript. The manuscript will undergo copyediting, typesetting, and review of the resulting proof before it is published in its final citable form. Please note that during the production process errors may be discovered which could affect the content, and all legal disclaimers that apply to the journal pertain.
} 


\section{Introduction}

Mitochondrial $\mathrm{BK}_{\mathrm{Ca}}$ channels (mitoBK $\mathrm{Ca}$ ) are safeguards of cardiac function as their activation protects the heart from ischemic insult, a property that is absent in the knockout animal (Xu et al., 2002; Singh et al., 2013; Soltysinska et al., 2014). One of the proposed mechanisms by which mitoBK $\mathrm{Ca}_{\mathrm{a}}$ activation favors cardiac health after ischemic insult is via improved mitochondrial $\mathrm{Ca}^{2+}$ handling and regulation of the mitochondrial permeability transition pore (mPTP) (Singh et al., 2013). Consistent with this idea, in other systems, mitoBK $_{\mathrm{Ca}}$ pharmacological inhibition produces cytochrome $c$ release, an event associated with the opening of the MPTP and cell death; while Bax (proapoptotic Bcl-2 associated protein X), a mPTP activator, inhibits channel activity (Cheng et al., 2011). In agreement with its protective role, the activation of cardiac mitoBK $\mathrm{Ca}_{\mathrm{improves}}$ basal mitochondrial energetic performance (Aon et al., 2010), whereas silencing $\mathrm{BK}_{\mathrm{Ca}}$ expression reduces cardiac oxidative phosphorylation (Soltysinska et al., 2014).

To exert its function in mitochondria, mitoBK $_{\mathrm{Ca}}$ must be first transported into this organelle and likely associate with partner proteins, as it does in other regions of the cell (Toro et al., 2013). Supporting this view, a two-hybrid system approach discovered that the regulatory $\beta 1$ subunit of $\mathrm{BK}_{\mathrm{Ca}}$ channels directly binds to a mitochondrial protein, cytochrome $c$ oxidase subunit I (Ohya et al., 2005).

We have previously demonstrated that the $\operatorname{mitoBK}_{\mathrm{Ca}}$ pore-forming a subunit is encoded by the same gene that encodes the plasma membrane $\mathrm{BK}_{\mathrm{Ca}}$ channel, Kcnmal, and that a 50 amino acid C-terminal splice insert (named DEC) favors $\mathrm{BK}_{\mathrm{Ca}}$ channel targeting into mitochondria of adult cardiomyocytes (Singh et al., 2013). Thus, the overall structure of the mitoBK $_{\mathrm{Ca}}$ channel is equivalent to that of the well-studied plasma membrane tetrameric channel, with each a-subunit composed of 7 transmembrane segments (S0-S6), a long intracellular C-terminus and an extracellular N-terminus (Meera et al., 1997). However, the protein partners of mitoBK $\mathrm{Ca}_{\mathrm{a}}$ are unknown.

Efforts to identify $\mathrm{BK}_{\mathrm{Ca}}$ channel partners at a large scale have been few and restricted to cochlea and brain preparations (Kathiresan et al., 2009; Gorini et al., 2010; Sokolowski et al., 2011; Singh et al., 2016). In this work, we have examined the interactome of mitoBK $\mathrm{Ca}$ in adult heart (isolated cardiomyocytes and whole ventricle), using a directed proteomic approach aided by co-immunoprecipitation with $\mathrm{BK}_{\mathrm{Ca}}$ antibodies and pull-down with recombinant DEC sequence. Two putative protein partners were selected to validate and further examine the regions in $\mathrm{BK}_{\mathrm{Ca}}$ involved in the associations: i) Tom22 from the mitochondrial import system, and ii) the adenine nucleotide translocator (ANT), which is linked to oxidative phosphorylation and the regulation of $\mathrm{MPTP}$.

\section{Materials and methods}

\subsection{Animals}

Sprague-Dawley male rats (3 months old) were used. Protocols received institutional approval. 


\subsection{Antibodies}

The following antibodies were used: Anti-BK $\mathrm{Ca}$ monoclonal antibody (mAb) (75-022, UC Davis/ NIH NeuroMab facility), Anti-BK $\mathrm{Ca}_{\text {pa }}$ polyclonal (p) Ab (APC-021, Alomone Labs), Anti-c-Myc mAb (M4439, Sigma), Anti-c-Myc polyclonal pAb (C3956, Sigma), Anti-HA mAb (H3663, Sigma), Anti-HA pAb (H6908, Sigma), anti-DDK mAb (TA50011, OriGene), Goat Anti-Rabbit IgG Alexa Fluor ${ }^{\circledR} 680$ conjugate (A21109, Invitrogen), and IRDye ${ }^{\circledR}$ 800CW Goat Anti-Mouse IgG (926-32210, Odyssey).

\subsection{Clones}

Full length human $\mathrm{BK}_{\mathrm{Ca}}$ a-subunit starting from Met1 $\left(\mathrm{BK}_{\mathrm{Ca}}\right)$ with or without $\mathrm{DEC}$ splice insert (EKKWFTDEPD NAYPRNIQIK PMSTHMANQI NQYKSTSSLI PPIREVEDEC) at the C-terminus were used in all experiments except for Figs. 4, 5 and 7 (see below). Compared to NCBI Accession No. U11058.2 (Wallner et al., 1995), which starts from Met3, constructs starting from Met1 have additional 96 amino acids at the N-terminus that includes a 3xHemagglutinin (HA)-tag upstream Met3 (MANGGGGGGG SSGGGGGGGG SSLRMSSNIH ANHLSLDASS SSSSSSSSSS SSSSSSSSSS VHEPKMYPYD VPDYAGYPYD VPDYAGSYPY DVPDYA; 3xHA tag sequences are in italics). $\mathrm{BK}_{\mathrm{Ca}}-\mathrm{DEC}$ has the C-terminal DEC sequence inserted downstream amino acids RDKQN as found in the heart (Singh et al., 2013). Clones starting from Met3 (Accession No. U11058.2) were either untagged or tagged at the N-terminus with c-Myc epitope (Meera et al., 1997) (Figs. 4 and 7) or with HA epitope (Fig. 5). Clones used in deletion constructs experiments (Figs. 4 and 7) were: $\mathrm{BK}_{\mathrm{Ca}}$ (1-1113); C-terminal deletion constructs 1-343, 1-441 and 1-711; and Nterminal deletion constructs 322-1113 and 679-1113; numbers correspond to NCBI Accession No. U11058.2. All $\mathrm{BK}_{\mathrm{Ca}}$ constructs were in pcDNA3. Tom22 construct was the human translocase of outer mitochondrial membrane 22 homolog (Accession No. NM_020243.4) with C-terminal c-Myc and DDK tags in pCMV6. ANT construct was the human mitochondrial adenine nucleotide translocator (Accession No. NM_001151.2) with a C-terminal c-Myc-DDK tag in pCMV6. Tom 22 and ANT clones were purchased from OriGene Technologies (Rockville, MD).

\subsection{Expression of recombinant fusion proteins in E. Coli}

Glutathione $S$-Transferase (GST)-DEC and GST in pGEX3 vector were transformed into $E$. coli BL21DE3 (Invitrogen) and cultured at $37{ }^{\circ} \mathrm{C}$ using Luria-Bertani (LB) broth (Thermo Fisher Scientific) supplemented with $100 \mathrm{ng} / \mathrm{mL}$ ampicillin until $\mathrm{OD}_{600}=0.5$. The expression of GST-DEC and GST was then induced by adding IPTG to a final concentration of $0.2 \mathrm{mM}$. Cultures were continued in a rotary shaker for $4 \mathrm{~h}$ at $37^{\circ} \mathrm{C}$. Bacteria were centrifuged at $1000 \mathrm{~g}$ for $5 \mathrm{~min}$ to collect the pellet. The pellet was further lysed using sonication (15 s) at power level 2 in lysis buffer (mM): 50 Tris, $\mathrm{pH} 7.4,100 \mathrm{NaCl}, 5 \mathrm{MgCl}_{2}$, $1 \%$ Triton X-100, 10\% glycerol, supplemented with fresh 2 mM DTT, $200 \mathrm{mM}$ PMSF and 1:500 dilution of protease inhibitor cocktail (11697498001, Roche).

\subsection{Isolation of cardiomyocytes from left ventricle}

Sprague-Dawley rats were anesthetized and injected with heparin (200 IU/kg, i.v.). After 15 min hearts were harvested in ice-cold Tyrode's solution (mM): $130 \mathrm{NaCl}, 5.4 \mathrm{KCl}, 1 \mathrm{MgCl}_{2}$, 
$0.6 \mathrm{Na}_{2} \mathrm{HPO}_{4}, 10$ glucose, 5 taurine, 10 2,3-butanedione monoxime, and 10 HEPES, pH 7.4, oxygenated with $95 \% \mathrm{O}_{2}-5 \% \mathrm{CO}_{2}(\mathrm{v} / \mathrm{v})$, and mounted on a modified Langendorff apparatus with an $80 \mathrm{~cm} \mathrm{H}_{2} \mathrm{O}$ constant pressure. After 5-10 min of perfusion with Tyrode's solution at $37^{\circ} \mathrm{C}$, the hearts were next perfused for 15 min with Tyrode's solution containing $372 \mathrm{U} / \mathrm{mL}$ Collagenase Type-2 and 1.0 U/mL Protease Type-XIV, and washed for 10-15 min with KB solution (mM): $25 \mathrm{KCl}, 10 \mathrm{KH}_{2} \mathrm{PO}_{4}, 5$ creatine, $2 \mathrm{MgSO}_{4}, 20$ glucose, 20 taurine, $100 \mathrm{~K}$ glutamate, 10 aspartic acid, 5 HEPES, 0.5 EGTA, and 1\% (wt/v) BSA, pH 7.2 oxygenated with $95 \% \mathrm{O}_{2}-5 \% \mathrm{CO}_{2}(\mathrm{v} / \mathrm{v})$. After washing, the left ventricles were tweezed into pieces in $\mathrm{KB}$ solution to release cells. Isolated cardiomyocytes were filtered through a $100 \mu \mathrm{m}$ strainer, and centrifuged at $1,000 \mathrm{~g}$ for $2 \mathrm{~min}$.

\subsection{Isolation of "crude" mitochondria and Percoll-purification}

i) "Crude" mitochondria. Isolated cardiomyocytes or left ventricles were homogenized with a Potter-Elvehjem homogenizer (20 rapid strokes) on ice and using isolation buffer A (mM): 70 sucrose, 210 mannitol, 50 Tris- $\mathrm{HCl}$, and $1 \mathrm{Na}_{2}$-EDTA, $\mathrm{pH}$ 7.4. The homogenate was centrifuged at 2,400 $\mathrm{g}$ for $5 \mathrm{~min}$ at $4^{\circ} \mathrm{C}$. The supernatant was then centrifuged at $17,000 \mathrm{~g}$ for $10 \mathrm{~min}$ at $4^{\circ} \mathrm{C}$. The pellet containing "crude" mitochondria was either further purified (ventricle samples) using Percoll gradient or directly resuspended in lysis buffer (isolated cardiomyocyte samples) (section 2.7). ii) Percoll purification. "Crude" mitochondria was carefully added onto $3 \mathrm{~mL}$ of 30\% (v/v) Percoll (Graham, 2001) in buffer B (mM): 250 sucrose, $10 \mathrm{Na}$-HEPES, $1 \mathrm{Na}_{2}$-EDTA, pH 7.4. Samples were centrifuged in a fixed angle rotor at 50,000 g for $45 \mathrm{~min}$. After ultracentrifugation, three clear layers were observed, and labeled as M1, M2 and M3 (Singh et al., 2012). The M3 fraction, corresponding to the purified mitochondria, was carefully isolated and resuspended in $1 \mathrm{~mL}$ of isolation buffer $\mathrm{A}$ and centrifuged at 17,000 $\mathrm{g}$ for $10 \mathrm{~min}$. The pellet was washed twice by resuspension with the same buffer and centrifuged again at 17,000 $\mathrm{g}$ for $5 \mathrm{~min}$ each. The purified mitochondria were lysed within $2 \mathrm{~h}$ after isolation.

\subsection{Mitochondria and cardiomyocyte lysates}

Mitochondria or isolated cardiomyocyte preparations were incubated at $4{ }^{\circ} \mathrm{C}$ (on a rotatory shaker for $1 \mathrm{~h}$ ) in cell lysis buffer ( 1 and $3 \mathrm{~mL}$, respectively) (mM): 50 Tris, $150 \mathrm{NaCl}, 5$ EDTA, 0.1\% Nonylphenyl Polyethylene Glycol (NP-40 alternative, Calbiochem), and 0.25\% Na-deoxycholate, $\mathrm{pH} 7.4$ supplemented with protease inhibitor cocktail (one tablet/50 mL) and $200 \mathrm{mM}$ PMSF. After lysis, samples were centrifuged at $17,000 \mathrm{~g}$ for $10 \mathrm{~min}$ at $4{ }^{\circ} \mathrm{C}$ and the supernatant was saved at $-80^{\circ} \mathrm{C}$ for future use. Protein concentration was measured with Bio-Rad Protein Assay method.

\subsection{Pull down assay and SDS-PAGE}

Recombinant fusion protein GST-DEC and GST (control) were used. Glutathione Sepharose 4B beads (GE healthcare) were first prewashed with bacteria lysis buffer and then incubated with $3 \mathrm{mg}$ of GST or GST-DEC on a rotatory shaker at $4{ }^{\circ} \mathrm{C}$ for $3 \mathrm{~h}$. After binding of GSTDEC and GST onto Glutathione Sepharose 4B beads, each sample was further washed with bacteria lysis buffer 3 times, following incubation with $2 \mathrm{mg}$ protein of cardiomyocyte cell lysates or mitochondrial lysates on a rotatory shaker at $4{ }^{\circ} \mathrm{C}$ for $2 \mathrm{~h}$. Each sample was then 
incubated with SDS loading buffer for $1 \mathrm{~h}$ at $37^{\circ} \mathrm{C}$ and centrifuged at $10,000 \mathrm{~g}$ for $3 \mathrm{~min}$. The supernatant was separated on a 4-20\% SDS-PAGE at room temperature. The protein bands were stained with SYPRO-RUBY stain according to the manufacturer's instructions (Bio-Rad).

\subsection{Immunoprecipitation for proteomics}

Mitochondrial lysates (see section 2.7) were precleared with $10 \mu \mathrm{L}$ protein $\mathrm{A} / \mathrm{G}$ resin/mg protein (Pierce Biotechnology Inc.) for $1 \mathrm{~h}$ at $4{ }^{\circ} \mathrm{C}$. Next, samples were centrifuged at 2,400 $\mathrm{g}$ for $5 \mathrm{~min}$ at $4{ }^{\circ} \mathrm{C}$ to remove protein $\mathrm{A} / \mathrm{G}$ resin. The supernatant was collected, and the protein concentration was calculated according to the Bio-Rad method. Anti-BK $\mathrm{Ca}$ antibodies $(2 \mu \mathrm{g})$ or IgGs $\left(2 \mu \mathrm{g}\right.$, control) were incubated for $2 \mathrm{~h}$ at $4{ }^{\circ} \mathrm{C}$ with $10 \mu \mathrm{L}$ protein $\mathrm{A} / \mathrm{G}$ resin on a rotatory shaker. Unbound antibodies were then removed by centrifugation 5 times at 2,400 $\mathrm{g}$ for $1 \mathrm{~min}$ at $4{ }^{\circ} \mathrm{C}$. Mitochondria lysates ( $2 \mathrm{mg}$ protein each) were added to immobilized anti-BK $\mathrm{Ca}$ and $\mathrm{IgG}$ antibodies, and incubated on a rotatory shaker overnight at $4{ }^{\circ} \mathrm{C}$. Samples were washed 5 times with cell lysis buffer at $2,400 \mathrm{~g}$ for 1 min each at $4{ }^{\circ} \mathrm{C}$. Laemmli sample buffer ( $30 \mu \mathrm{L}$ of $3 \mathrm{X}$ buffer) was added, and samples were incubated at $37^{\circ} \mathrm{C}$ for $1 \mathrm{~h}$. Eluted proteins were centrifuged at $17,000 \mathrm{~g}$ for $10 \mathrm{~min}$ at $4{ }^{\circ} \mathrm{C}$, and separated on a $4-20 \%$ SDS-PAGE at room temperature. Protein bands were then stained with SYPRORUBY.

\subsection{Mass spectrometry analysis of proteins}

Plugs of SYPRO-RUBY stained 1-D gels containing GST- and GST-DEC bound proteins or anti-BK $\mathrm{Ca}_{\mathrm{Ca}}$ and $\mathrm{IgG}$ bound proteins were excised using a sterile scalpel blade. Sections ( 2 $\mathrm{mm}$ ) ranging from $10 \mathrm{kDa}$ to $250 \mathrm{kDa}$ were collected and further digested with trypsin. Protein digestion and elution were carried as described earlier (Singh et al., 2009; Singh et al., 2013). Liquid chromatography, mass spectrometry in tandem (LC/MS/MS) was performed using a Thermo LTQ-Orbitrap XL mass spectrometer equipped with an Eksigent Nano Liquid chromatography-1D plus system and an Eksigent auto sampler at the University of California Los Angeles W. M. Keck Proteomic Center. Sequences were assigned using the Swiss-Prot Rat database and the MASCOT Daemon search engine. The output data included MASCOT score, molecular weight, number of peptides matched, peptide sequences, sequence coverage, rank, and p-value. To select candidate proteins, the score value of individual spectra was set at a $95 \%$ confidence level and a MASCOT score > or $=21$. Peptides were selected as specified by the Peptide Prophet algorithm. GST-DEC or $\mathrm{BK}_{\mathrm{Ca}}$ specific interacting proteins were defined as those not found in the samples using GST alone or $\mathrm{IgG}$, respectively.

\subsection{Cell culture}

HEK293T cells were cultured in Dulbecco's Modified Eagle Medium (DMEM, Gibco) supplemented with $10 \%$ (v/v) FBS, 2 units $/ \mathrm{mL}$ streptomycin and penicillin at $37{ }^{\circ} \mathrm{C}$ in a humidity-controlled $\mathrm{CO}_{2}[5 \%(\mathrm{v} / \mathrm{v})]$ incubator. 


\subsection{Transient transfection}

HEK293T cells were transfected at 70\% confluence using Lipofectamine 2000 (Invitrogen)

following the manufacturer's instructions. Plasmid DNAs were incubated with Lipofectamine 2000 in OPTI-MEM (Invitrogen) for $20 \mathrm{~min}$ at room temperature $\left(20-25^{\circ} \mathrm{C}\right)$. Plasmid-Lipofectamine mixtures were then incubated with cells in OPTI-MEM at $37^{\circ} \mathrm{C}$ in a $\mathrm{CO}_{2}$ incubator for 5-7 h. Afterwards, DMEM containing 20\% FBS was added to reach a final FBS concentration of $10 \%$. Because cotransfection of Tom 22 or ANT with $\mathrm{BK}_{\mathrm{Ca}}$ significantly decreased the expression of $\mathrm{BK}_{\mathrm{Ca}}$, we first transfected $\mathrm{BK}_{\mathrm{Ca}}$ constructs to allow their expression followed by a second transfection of Tom 22 or ANT $24 \mathrm{~h}$ later. All constructs were transfected with $10 \mu \mathrm{g}$ plasmid/100 mm dish with the exception of Tom22 that was transfected at $1 \mu \mathrm{g}$ plasmid/100 mm dish in experiments involving truncated $\mathrm{BK}_{\mathrm{Ca}}$ channels. After $48 \mathrm{~h}$ from the second transfection, cells were collected and lysed for further analysis.

\subsection{Western blot}

HEK293T cells or cellular fractions were treated with cell lysis buffer (see section 2.7) containing protease inhibitor cocktail (one tablet $/ 50 \mathrm{~mL}$ ), and incubated for $30 \mathrm{~min}$ at $4{ }^{\circ} \mathrm{C}$ with shaking. Samples were then centrifuged at $17,000 \mathrm{~g}$ for $10 \mathrm{~min}$ at $4{ }^{\circ} \mathrm{C}$, and the supernatant was collected as lysates. Lysate proteins ( $20 \mu \mathrm{g} / \mathrm{lane})$ were separated on 4-20\% SDS/PAGE and transferred to nitrocellulose membranes. Nitrocellulose membranes were blocked with $5 \%$ (wt/v) milk in TBS (150 mM NaCl, $20 \mathrm{mM}$ Tris-HCl, $\mathrm{pH} 7.4)$ at room temperature for $60 \mathrm{~min}$ and incubated with antibodies $(2 \mu \mathrm{g} / \mathrm{mL})$ overnight. Next day, membranes were washed 3 times with TBS and incubated with $0.01 \mu \mathrm{g} / \mathrm{mL}$ secondary Abs for $1 \mathrm{~h}$ at room temperature. After washing 3 times, membranes were visualized and scanned with the Odyssey Imaging System (Li-Cor Biosciences).

\subsection{Co-immunoprecipitation of heterologously expressed proteins}

HEK293T cells expressing different combinations of $\mathrm{BK}_{\mathrm{Ca}}$ constructs, Tom22 or ANT were cultured on $100 \mathrm{~mm}$ dish and lysed with cell lysis buffer containing protease inhibitor cocktail. Lysates were centrifuged at $17,000 \mathrm{~g}$ for $10 \mathrm{~min}$ at $4{ }^{\circ} \mathrm{C}$ and the supernatant was cleared with $10 \mu \mathrm{L}$ protein $\mathrm{A} / \mathrm{G}$ resin/mg protein for $1 \mathrm{~h}$ at $4{ }^{\circ} \mathrm{C}$ on a rotatory shaker. The precleared lysates (1 mg protein) were incubated with $10 \mu \mathrm{L}$ protein $\mathrm{A} / \mathrm{G}$ resin preconjugated with $2 \mu \mathrm{g}$ antibodies (Anti-HA mAb or anti-BK $\mathrm{Ca}$ mAb for $\mathrm{BK}_{\mathrm{Ca}}$ and $\mathrm{BK}_{\mathrm{Ca}^{-}}$ DEC; anti-c-Myc mAb for Tom22, ANT, and $\mathrm{BK}_{\mathrm{Ca}}$ constructs; anti-DDK mAb for Tom22 and ANT; and Flag pAb for ANT) in a total volume of $500 \mu \mathrm{L}$ overnight at $4{ }^{\circ} \mathrm{C}$. After incubation, samples were centrifuged at 2,400 $\mathrm{g}$ for $1 \mathrm{~min}$ and washed for 5 times with cell lysis buffer. The proteins were eluted from the beads with $30 \mu \mathrm{L} 3 \mathrm{X}$ Laemmli sample buffer at $37^{\circ} \mathrm{C}$ for $1 \mathrm{~h}$. After elution, samples were centrifuged at $17,000 \mathrm{~g}$ for $10 \mathrm{~min}$ at $4{ }^{\circ} \mathrm{C}$ and separated on 4-20\% SDS-PAGE along with whole cell lysates. Separated proteins were transferred to nitrocellulose membranes and immunoblotted with respective antibodies (1 $\mu \mathrm{g} / \mathrm{mL}$ ). Single- or double-labeled immunoblots were imaged as described above. 


\subsection{Cell fractionation}

HEK293T cells were collected and homogenized in isolation buffer A (mM): 70 sucrose, 210 mannitol, $1 \mathrm{Na}_{2}$-EDTA, 50 Tris-HCl, pH 7.4 using a Potter-Elvehjem homogenizer (3 rapid strokes). The homogenate was centrifuged at 2,400 $\mathrm{g}$ for $5 \mathrm{~min}$ in an Eppendorf tube. The supernatant was collected and centrifuged at 17,000 $\mathrm{g}$ for $10 \mathrm{~min}$. The pellet containing "crude" mitochondria was resuspended in $50 \mu \mathrm{L}$ of isolation buffer $\mathrm{A}$, and the supernatant was kept. The "crude" mitochondria preparation was further purified by Percoll gradient centrifugation (see section 2.6) and lysed within $2 \mathrm{~h}$ after isolation. The supernatant after isolating the "crude" mitochondria was used to isolate the "crude" membrane fraction and cytosolic fraction. The supernatant was centrifuged in the same fixed angle rotor at 100,000 $\mathrm{g}$ for $30 \mathrm{~min}$. The pellet was collected as "crude" membrane fraction. The supernatant containing ribosomes and cytosol was named here cytosolic fraction. All fractions were lysed in cell lysis buffer (see section 2.7) for Western blot analysis together with whole-cell lysate.

\subsection{Statistics}

Data are presented as means \pm S.E. Statistical comparisons between groups were made using Student's $t$ test. Multiple comparisons were done with ANOVA followed by the Tukey test. A $p$ value $<0.05$ was considered statistically significant. All experiments were performed using at least three independent preparations.

\section{Results}

\subsection{Identification of mitoBK $\mathrm{Ca}_{\text {-associated cardiac mitochondrial proteins }}$}

mitoBK $\mathrm{Ca}_{\mathrm{Cassociated}}$ proteins were identified using a directed proteomic approach using recombinant GST-DEC and specific anti-BK $\mathrm{Ca}_{\mathrm{CA}} \mathrm{mAb}$ (Misonou et al., 2006). The $\mathrm{BK}_{\mathrm{Ca}} \mathrm{C}$ terminal DEC insert is known to support $\mathrm{BK}_{\mathrm{Ca}}$ mitochondrial expression in adult cardiomyocytes (Singh et al., 2013), and thus, was expected to associate with mitochondrial partners. Three protocols were used to maximize the isolation of $\mathrm{BK}_{\mathrm{Ca}}$ protein partners: 1) pull down from "crude" mitochondria of isolated cardiomyocytes using GST-DEC and GST (control); 2) pull down from Percoll-purified mitochondria of left ventricle using anti-BK $\mathrm{Ca}$ $\mathrm{mAb}$ and $\operatorname{IgG}$ (control); and 3) pull down from whole cardiomyocytes with GST-DEC and GST (control).

The "crude" mitochondria preparation had the advantage of using solely rat cardiomyocytes. However, due to material limitations, further Percoll purification of this preparation was impractical; instead, we used the GST-DEC fusion protein that, we expected, would favor specific recognition of mitochondrial proteins. To identify proteins interacting with $\mathrm{BK}_{\mathrm{Ca}}$ regions other than $\mathrm{DEC}$, we used a specific $\mathrm{BK}_{\mathrm{Ca}} \mathrm{mAb}$ to immunoprecipitate proteins from the Percoll-purified mitochondria. We also investigated whether GST-DEC could pick up mitochondrial interacting proteins in whole ventriculocyte lysates. Indeed, with this approach using the whole ventriculocyte lysates with GST-DEC as bait yielded 49 mitochondrial partners out of a total of 341 partners ( 14\% mitochondrial proteins; in 3 independent experiments). This result is consistent with experiments using: i) GST-DEC to pull down proteins in "crude" mitochondria from isolated cardiomyocytes that revealed 68 
mitochondrial partners out of a total of 561 partners ( 12\% mitochondrial proteins; in 3 independent experiments), and ii) anti- $\mathrm{BK}_{\mathrm{Ca}} \mathrm{mAb}$ to immunoprecipitate proteins from Percoll-purified mitochondria from left ventricle that detected 77 mitochondrial partners out of a total of 428 partners ( 17\%; in 3 independent experiments). Overall, a total of 1079 different proteins were identified as partners of $\mathrm{BK}_{\mathrm{Ca}}$ in cardiomyocytes and left ventricle using the above mentioned protocols. The locations were catalogued into intracellular organelles i.e. mitochondrion (151 proteins), endoplasmic reticulum (44 proteins), Golgi (17 proteins), and nucleus (151 proteins) (Tables 1 and 2); cytoplasm (322 proteins); and plasma membrane ( 223 proteins). The remaining 171 proteins were catalogued as "others" by the UniProt Knowledgebase.

In this work, we focused our analysis on the 151 mitochondrial proteins (Table 1). A functional annotation analysis of these proteins using the bioinformatic tool Database for Annotation, Visualization and Integrated Discovery (DAVID) revealed that $\mathrm{BK}_{\mathrm{Ca}}$ channel is associated with 13 distinctive biological processes in the mitochondria (Fig. 1A). Among those, of special interest were import mechanisms (8 proteins), oxidative phosphorylation (28 proteins), transport ( 7 proteins), TCA cycle (9 proteins), fatty acid metabolism ( 5 proteins), and programmed cell death (8 proteins). As an example, a mass spectrum obtained for the adenine nucleotide translocator, ANT is given in Fig. 1B. The uncovered relationship between $\mathrm{BK}_{\mathrm{Ca}}$ channel and the predicted biological activities underscores the potential role of $\mathrm{BK}_{\mathrm{Ca}}$ channel in contributing to the functional integrity of mitochondria and consequently of cardiac cells.

\section{2. mitoBK $_{\mathrm{Ca}}$ interacts with Tom22 in HEK293T cells}

One of the partners found in the interactome associated with the DEC sequence was Tom22 (matching peptide LQMEQQQQLQQR; Table 1), a protein located on the outer mitochondrial membrane. Tom22 is known to serve as an initial recognition site for protein import into mitochondria (Mayer et al., 1995). Thus, we deemed it important to corroborate its association with $\mathrm{BK}_{\mathrm{Ca}}$ as this would permit to start setting the building blocks of mitoBK $\mathrm{Ca}_{\mathrm{import}}$ pathway. Thus, we co-expressed $\mathrm{BK}_{\mathrm{Ca}}$ with or without DEC (3HA-tagged $\mathrm{N}$-terminal of Met3) with Tom22 (C-terminal c-Myc tagged) in HEK293T cells for coimmunoprecipitation analysis by immunoprecipitating $\mathrm{BK}_{\mathrm{Ca}}$ or $\mathrm{BK}_{\mathrm{Ca}}-\mathrm{DEC}$ and examining the immunoprecipitation products for Tom22. As controls, we also expressed each protein alone.

Figure $2 \mathrm{~A}$ shows in the same blot the immunoprecipitation of $\mathrm{BK}_{\mathrm{Ca}}$ and $\mathrm{BK}_{\mathrm{Ca}}-\mathrm{DEC}$ together with the successful co-immunoprecipitation of Tom 22 by both $\mathrm{BK}_{\mathrm{Ca}}$ variants. In separate experiments, immunoprecipitation of Tom 22 yielded bands of similar sizes as the ones observed in the co-immunoprecipitation products confirming Tom22 molecular size (not shown). The strong signal near $100 \mathrm{kDa}$ likely corresponds to IgG composite or nonspecific labeling of the secondary antibody. The specificity of the co-immunoprecipitation was confirmed by reverse coimmunoprecipitation with $\mathrm{BK}_{\mathrm{Ca}}$ (see section 3.4). Fig. $2 \mathrm{~B}$ demonstrates in the same blot the proper expression of each clone in the input lysates. The co-immunoprecipitation (Co-IP) efficiency of the two $\mathrm{BK}_{\mathrm{Ca}}$ variants was calculated as previously described ( $\mathrm{Li}$ et al., 2013) by the ratio of the band intensities of co- 
immunoprecipitated Tom22 (as in Fig. 2A, squares) to those of immunoprecipitated $\mathrm{BK}_{\mathrm{Ca}}$ variant (as in Fig. 2A, arrows), and normalized to the corresponding Tom22 signals in the input lysates (as in Fig. 2B, arrowhead). Figure $2 \mathrm{C}$ shows the mean values demonstrating that $\mathrm{BK}_{\mathrm{Ca}}$ and $\mathrm{BK}_{\mathrm{Ca}}-\mathrm{DEC}$ had a similar ability to interact with Tom22 (0.89 \pm 0.18 vs. $0.91 \pm 0.15 ; \mathrm{n}=3$ each). These results are consistent with the proteomic data and demonstrate that Tom22 association with $\mathrm{BK}_{\mathrm{Ca}}$ in HEK293T cells does not depend on the presence of DEC sequence in $\mathrm{BK}_{\mathrm{Ca}}$.

\subsection{Both mitoBK $\mathrm{Ca}_{\mathrm{a}}$ and Tom22 are imported into mitochondria of HEK293T cells}

We next examined the subcellular localization of co-expressed Tom22 and $\mathrm{BK}_{\mathrm{Ca}}$ through cell fractionation and immunoblotting. Figure 3A,B (upper panels) and Fig. 3C,D show that both $\mathrm{BK}_{\mathrm{Ca}}$ and $\mathrm{BK}_{\mathrm{Ca}}$-DEC were significantly enriched in the "crude" mitochondria fraction (Cmito). Importantly, $\mathrm{BK}_{\mathrm{Ca}}$ isoforms were also detected in the purified mitochondria fraction (Pmito), indicating that $\mathrm{BK}_{\mathrm{Ca}}$ was imported into mitochondria in HEK293T cells. Interestingly, Tom22 was found in all of the fractions examined (A,B, bottom panels; E) including the cytosol and crude membranes. This finding cannot be explained by inadequate separation since, as shown later in section 3.6, a typical mitochondrial marker, ANT, was only present in "crude" and purified mitochondrial fractions. The mean relative abundance values of $\mathrm{BK}_{\mathrm{Ca}}$ and $\mathrm{BK}_{\mathrm{Ca}}$-DEC in Fig. 3C,D show a very similar pattern of expression in the different subcellular fractions. Both variants gave the strongest signal in "crude" mitochondria $\left(\mathrm{BK}_{\mathrm{Ca}}=1.62 \pm 0.13\right.$ and $\mathrm{BK}_{\mathrm{Ca}}-\mathrm{DEC}=1.26 \pm 0.11, \mathrm{n}=3$ each) suggesting that the majority of $\mathrm{BK}_{\mathrm{Ca}}$ channels were localized to mitochondria or in mitochondria-associated membranes. In agreement, the purified mitochondria fraction displayed a considerable amount of $\mathrm{BK}_{\mathrm{Ca}}$ channel signal $\left(\mathrm{BK}_{\mathrm{Ca}}=0.73 \pm 0.09, \mathrm{BK}_{\mathrm{Ca}}-\mathrm{DEC}=0.45 \pm 0.17, \mathrm{n}=3\right.$, each). As expected from previous studies (Ma et al., 2007) both variants were also present in "crude" membranes $\left(\mathrm{BK}_{\mathrm{Ca}}=0.36 \pm 0.07, \mathrm{BK}_{\mathrm{Ca}}-\mathrm{DEC}=0.65 \pm 0.20, \mathrm{n}=3\right.$ each $)$, whereas their presence in the cytosolic fraction was minimal $\left(\mathrm{BK}_{\mathrm{Ca}}=0.02 \pm 0.03, \mathrm{BK}_{\mathrm{Ca}}-\mathrm{DEC}=0.02 \pm 0.001, \mathrm{n}=3\right.$ each $)$.

The mean relative quantification of Tom22 in different fractions is shown in Fig. 3E. As stated earlier, Tom22 distribution spanned all fractions examined. Nevertheless, the expression and distribution of Tom 22 in the "crude" mitochondria $(0.94 \pm 0.20, \mathrm{n}=6$ each) and the purified mitochondria $(0.59 \pm 0.25, \mathrm{n}=6$ each) was robust. Thus, the results indicate that both $\mathrm{BK}_{\mathrm{Ca}}$ variants and Tom22 are targeted into mitochondria, though not exclusively, in HEK293T cells.

\subsection{The $\mathrm{BK}_{\mathrm{Ca}}$ channel interacts with Tom22 through its transmembrane region}

To identify the regions in $\mathrm{BK}_{\mathrm{Ca}}$ channel relevant for its association with Tom22, we performed coimmunoprecipitations with $\mathrm{BK}_{\mathrm{Ca}} \mathrm{N}$ - and C-terminal deletions. Figure $4 \mathrm{~A}$ shows a scheme of wild-type $\mathrm{BK}_{\mathrm{Ca}}$ (1-1113 amino acids) where the arrows delineate the regions spanned by each construct (the numbers correspond to the amino acids numbering). All $\mathrm{BK}_{\mathrm{Ca}}$ constructs were tagged with c-Myc epitope at the $\mathrm{N}$-terminus. C-terminal truncates were: 1-343, 1-441 and 1-711; N-terminal deletion constructs were: 322-1117 covering the whole $\mathrm{C}$-terminus and 679-1113 that includes the regulator for potassium conductance 2 (RCK2) domain, also called the "tail" region. Tom22 contained a DDK tag at the C-terminus. HEK293T cells were transfected with $\mathrm{BK}_{\mathrm{Ca}}$ constructs alone (control) or in 
conjunction with Tom22, and with Tom22 alone (control). All samples were subjected to immunoprecipitation using anti-DDK mAb targeting Tom22, and different truncated $\mathrm{BK}_{\mathrm{Ca}}$ proteins were detected with anti-c-Myc pAb (Fig. 4B, top). The co-immunoprecipitated signals of 1-343, 1-441, and 1-711 constructs were strong (lanes 8-10, solid squares) compared to the background signals of $\mathrm{BK}_{\mathrm{Ca}}$ proteins expressed alone (lanes 1-3, dashed squares), whereas co-immunoprecipitated C-terminus (322-1113) and "tail" (679-1113) were barely detected (lanes 11,12, solid squares) and practically absent in the control (lanes 4 and 5, dashed squares). As reference, lane 13 shows the co-immunoprecipitated wild type $\mathrm{BK}_{\mathrm{Ca}}$. Note that this coimmunoprecipitation corresponds to the reverse coimmunoprecipitation of Fig. 2A. Figure 4B (bottom panel) shows the successful immunoprecipitation of Tom 22 for the same experiment, and Fig. $4 \mathrm{C}$ displays the expression of all clones in the input lysates. The co-immunoprecipitation (co-IP) efficiency of different $\mathrm{BK}_{\mathrm{Ca}}$ regions was calculated by first subtracting the corresponding background signals from the coimmunoprecipitation signals of $\mathrm{BK}_{\mathrm{Ca}}$ constructs (as in Fig. $4 \mathrm{~B}$, top) and normalizing to the corresponding immunoprecipitated Tom 22 (as in Fig. $4 \mathrm{~B}$, bottom) and $\mathrm{BK}_{\mathrm{Ca}}$ input signals (as in Fig. 4C, top, lanes 8-13). The co-IP efficiency value of wild-type $\mathrm{BK}_{\mathrm{Ca}}$ was set to 1 . Constructs 1-343, 1-441, and 1-711 showed a similar ability to interact with Tom22 $(1-343=3.43 \pm 0.90,1-441=2.42 \pm 0.60,1-711=2.04 \pm 0.42 ; n=3$ each, $p>0.05)$, which is much higher than that observed for wild-type $\mathrm{BK}_{\mathrm{Ca}}$. In contrast, both the $\mathrm{C}$-terminus and tail lost their ability to efficiently coimmunoprecipitate Tom 22 (C-terminus $=0.33 \pm 0.05$, tail $=0.42 \pm 0.21 ; \mathrm{n}=3$ each). Note that although construct $1-711$ contains part of the $\mathrm{C}$ terminus (up to the first amino acids of the "tail" segment) it maintained a significant interaction with Tom22. Taken together, the results suggest that the interaction between $\mathrm{BK}_{\mathrm{Ca}}$ channel and Tom22 is mainly through the transmembrane domain of $\mathrm{BK}_{\mathrm{Ca}}$ channel and that the "tail" region exerts an inhibitory action on the association of both proteins.

\section{5. mitoBK $\mathrm{Ca}_{\mathrm{Ca}}$ interacts with ANT in HEK293T cells}

From the potential partners of $\mathrm{BK}_{\mathrm{Ca}}$ in Table 1, we next selected ANT (matching peptides TAVAPIE, YFPTQALNFAFK) to substantiate the association of the two proteins by biochemical means. Although the analysis software reported ANT2 as the matching protein, the identified peptides are identical in ANT1, which is the isoform that predominates in heart tissue (Graham et al., 1997; Dorner et al., 1999). ANT is of special interest: in addition to its role in exchanging ADP/ATP across the inner mitochondrial membrane, ANT serves as regulator of the mPTP (Morciano et al., 2015; Halestrap and Richardson, 2015). Moreover, its potential association with mitoBK $\mathrm{Ca}_{\mathrm{Ca}}$ offers a molecular link between regulatory components of the mPTP and the role of mitoBK $_{\mathrm{Ca}}$ in the regulation of mPTP (Cheng et al., 2011; Singh et al., 2013).

Figure 5A shows co-immunoprecipitation experiments performed using HEK293T cells coexpressing ANT (c-Myc-DDK tagged) with $\mathrm{BK}_{\mathrm{Ca}}$ (untagged) and $\mathrm{BK}_{\mathrm{Ca}}-\mathrm{DEC}$ (HA tagged) (lanes 4 and 5) or expressing $\mathrm{ANT}, \mathrm{BK}_{\mathrm{Ca}}-\mathrm{DEC}$ or $\mathrm{BK}_{\mathrm{Ca}}$ alone (lanes 1-3). In these experiments, we immunoprecipitated $\mathrm{BK}_{\mathrm{Ca}}$ and tested the blots for $\mathrm{BK}_{\mathrm{Ca}}$ as control (Fig. 5A, top panel) and for co-immunoprecipitated ANT (Fig. 5A, lower panel). Signals of coimmunoprecipitated ANT (squares, lanes 4 and 5) were only present when both ANT and $\mathrm{BK}_{\mathrm{Ca}}$ (or $\mathrm{BK}_{\mathrm{Ca}}$-DEC) were co-expressed. Confirming the molecular mass of ANT, its 
immunoprecipitation yielded products with similar molecular mass (not shown). For reverse co-immunoprecipitation see Fig. 7 (lane 13). Fig. 5B demonstrates proper expression of all clones in the input lysates. Note that although expression of $\mathrm{BK}_{\mathrm{Ca}}-\mathrm{DEC}$ was lower in the input lysate (Fig. 5B, upper panel, lanes 2 and 4), its immunoprecipitation was quite efficient yielding bands as intense as those for $\mathrm{BK}_{\mathrm{Ca}}$ (Fig. 5A, top panel). The co-

immunoprecipitation efficiency, calculated as in Fig. 2E, demonstrates that the DEC sequence in $\mathrm{BK}_{\mathrm{Ca}}-\mathrm{DEC}$ enhances the ability of ANT to associate with $\mathrm{BK}_{\mathrm{Ca}}$ by $\sim 30 \%$ (from $0.69 \pm 0.02$ to $1, \mathrm{n}=3$ ). This result is in contrast to Tom22, which interacted equally well with both $\mathrm{BK}_{\mathrm{Ca}}$ and $\mathrm{BK}_{\mathrm{Ca}}-\mathrm{DEC}$.

\section{6. mitoBK $\mathrm{Ca}$ and ANT are imported into mitochondria of HEK293T cells}

Next, we investigated the subcellular localization of $\mathrm{BK}_{\mathrm{Ca}}$ (or $\mathrm{BK}_{\mathrm{Ca}}-\mathrm{DEC}$ ) and ANT coexpressed in HEK293T cells using cell fractionation and double-labeled immunoblots. Figure 6 illustrates the distribution of $\mathrm{BK}_{\mathrm{Ca}}(\mathrm{A})$ and $\mathrm{BK}_{\mathrm{Ca}}-\mathrm{DEC}(\mathrm{B})$ when co-expressed with ANT. Bands around $\sim 135 \mathrm{kDa}$ correspond to $\mathrm{BK}_{\mathrm{Ca}}(\mathrm{A})$, at $\sim 140 \mathrm{kDa}$ correspond to $\mathrm{BK}_{\mathrm{Ca}^{-}}$ DEC (B) and bands at $\sim 32 \mathrm{kDa}$ correspond to ANT (A,B). In contrast to Tom 22 that distributed along all fractions (Fig. 3), ANT showed a clear-cut enrichment in the "crude" and purified mitochondrial fractions indicating that at the time of cell harvesting the vast majority, if not all, synthesized ANT had reached its mitochondrial destination. In line with this view, no signals were detected in the "crude" membrane or cytosolic fractions (within the resolution of our immunoblots). On the other hand, $\mathrm{BK}_{\mathrm{Ca}}$ and $\mathrm{BK}_{\mathrm{Ca}}-\mathrm{DEC}$ followed the same expression trend as when co-expressed with Tom22 (Fig. 3) with both $\mathrm{BK}_{\mathrm{Ca}}$ and $\mathrm{BK}_{\mathrm{Ca}}-\mathrm{DEC}$ concentrated in the "crude" mitochondrial fraction but still detected in the purified mitochondrial fraction.

The mean relative abundance of each protein in the different fractions with respect to cell lysates (set to 1) is shown in Fig. 6C-E. Mean values for $\mathrm{BK}_{\mathrm{Ca}}(\mathrm{C})$ and $\mathrm{BK}_{\mathrm{Ca}}-\mathrm{DEC}$ (D) in "crude" mitochondria fractions were: $\mathrm{BK}_{\mathrm{Ca}}=1.96 \pm 0.002$ and $\mathrm{BK}_{\mathrm{Ca}}-\mathrm{DEC}=1.68 \pm 0.10(\mathrm{n}=3$ each), and in the purified mitochondria fraction were: $\mathrm{BK}_{\mathrm{Ca}}=0.56 \pm 0.10$ and $\mathrm{BK}_{\mathrm{Ca}^{-}}$ $\mathrm{DEC}=0.31 \pm 0.10$ ( $\mathrm{n}=3$ each). In contrast, the distribution in the "crude" membrane and cytosolic fractions were minimal with the exception of $\mathrm{BK}_{\mathrm{Ca}}$-DEC in "crude" membranes ("crude" membranes: $\mathrm{BK}_{\mathrm{Ca}}=0.23 \pm 0.10, \mathrm{BK}_{\mathrm{Ca}}-\mathrm{DEC}=0.57 \pm 0.10$; cytosol: $\mathrm{BK}_{\mathrm{Ca}}=0.06 \pm 0.03$, $\mathrm{BK}_{\mathrm{Ca}}-\mathrm{DEC}=0.02 \pm 0.03 ; \mathrm{n}=3$ each). ANT mean relative abundance values (E) demonstrated a vast enrichment (32 times) in the purified mitochondrial fraction and a robust segregation in the "crude" mitochondria fraction (10 times) with respect to cell lysates. Mean values were: $32.05 \pm 0.99$ and $9.70 \pm 3.20$ ( $n=3$ each), respectively. These results are consistent with the fact that ANT is the most abundant protein in the inner mitochondrial membrane (Liu and Chen, 2013) and validate the cell fractionation protocol used here. Moreover, they indicate that the association between $\mathrm{ANT}$ and $\mathrm{BK}_{\mathrm{Ca}}$ must occur in mitochondria.

\subsection{ANT interacts with $\mathrm{BK}_{\mathrm{Ca}}$ through the channel transmembrane domain}

Figure 5C showed that the presence of the DEC sequence can facilitate, but does not determine, the interaction between $\mathrm{BK}_{\mathrm{Ca}}$ and ANT. Thus, other regions in $\mathrm{BK}_{\mathrm{Ca}}$ must be of relevance for the association between the two molecules. To address this point, we performed coimmunoprecipitation experiments to define the major region(s) in $\mathrm{BK}_{\mathrm{Ca}}$ 
involved in its association with ANT. The same deletion constructs as in Fig. 4C that lack DEC insert were co-expressed or not (control) with ANT in HEK293T cells. Figure 7A shows an example of a coimmunoprecipitation experiment using anti-DDK mAb to immunoprecipitate ANT and anti-c-Myc pAb to detect immunoprecipitated ANT and coimmunoprecipitated $\mathrm{BK}_{\mathrm{Ca}}$ proteins in the same blot. Lanes 8-13 show the coimmunoprecipitated $\mathrm{BK}_{\mathrm{Ca}}$ constructs together with the immunoprecipitated ANT; lanes 1-6 show the corresponding background signals in the absence of ANT expression and lane 7 shows expression of ANT alone.

Signals of 1-343, 1-441, and 1-711 were strong (lanes 8-10, squares), whereas, the Cterminus (322-1113) and "tail" (679-1113) signals were low (lanes 11-12, squares). As reference, lane 13 shows the co-immunoprecipitation of wild type $\mathrm{BK}_{\mathrm{Ca}}$. Note that the coimmunoprecipitated $\mathrm{BK}_{\mathrm{Ca}}$ signals (squares) are much stronger than the corresponding background signals (dashed squares). The immunoblot of corresponding input lysates is shown in Fig. 7B. After subtraction of background signals, the co-immunoprecipitation signals of $\mathrm{BK}_{\mathrm{Ca}}$ constructs were normalized to the corresponding ANT signals in the immunoprecipitates and to the $\mathrm{BK}_{\mathrm{Ca}}$ signals in the input lysates to obtain the Co-IP efficiency compared to wild-type $\mathrm{BK}_{\mathrm{Ca}}$. Compared to wild-type $\mathrm{BK}_{\mathrm{Ca}}$, the Co-IP efficiency was higher for constructs $1-343$ and $1-441(1-343=2.05 \pm 0.69 ; 1-441=1.65 \pm 0.34 ; n=3$ each). Protein 1-711 showed very similar ability to interact with ANT $(0.91 \pm 0.20, \mathrm{n}=3$ each) compared to the full length $\mathrm{BK}_{\mathrm{Ca}}$; whereas, the $\mathrm{C}$-terminus $322-1113(0.17 \pm 0.05, \mathrm{n}=3$ each) and "tail" 679-1113 $(0.33 \pm 0.03, \mathrm{n}=3$ each $)$ had a marked decrease in their ability to associate with ANT. Overall, the results indicate that in HEK293T cells the interaction between $\mathrm{BK}_{\mathrm{Ca}}$ and ANT is mainly through the transmembrane domain of $\mathrm{BK}_{\mathrm{Ca}}$ (1-343) and that the whole C-terminus and not only the "tail" as for Tom 22 exerts an inhibitory effect in the interaction.

\section{Discussion}

\subsection{Cardiac $\mathrm{BK}_{\mathrm{Ca}}$ mitochondrial interactome: physiological relevance}

This study is the first to address the potential interactome of $\mathrm{BK}_{\mathrm{Ca}}$ channels specifically in mitochondria, in particular of cardiac mitochondria. In total, we identified 151 mitochondrial proteins that can interact with $\mathrm{BK}_{\mathrm{Ca}}$. These partner proteins are involved in 13 physiological mitochondrial functions, including oxidative phosphorylation, TCA cycle, import, and metabolism (Fig. 1 and Table 1). We focused on the heart because mitoBK $_{\mathrm{Ca}}$ has a proven physiological role in this organ, acting as a shield from ischemia and reperfusion injury ( $\mathrm{Xu}$ et al., 2002; Singh et al., 2013; Soltysinska et al., 2014; Balderas et al., 2015), while its activity improves basal mitochondrial respiratory performance (Aon et al., 2010). Moreover, in astrocytoma cells mitoBK $\mathrm{Ca}_{\mathrm{C}}$ electrical activity is influenced by substrates of oxidative phosphorylation (Bednarczyk et al., 2013). Consistent with these functional studies, we found mitochondrial $\mathrm{BK}_{\mathrm{Ca}}$ partner proteins belonging to four complexes (complex I, III, IV, and V) of the respiratory chain including ATP synthase, cytochrome $c$ oxidase and NADH dehydrogenase. Interestingly, in our previous whole brain proteomic studies, we also found these respiratory chain proteins forming part of the $\mathrm{BK}_{\mathrm{Ca}}$ interactome (Singh et al., 2016). It is worth mentioning that cytochrome $c$ oxidase subunit 1 directly binds to the regulatory $\beta 1$ subunit of $\mathrm{BK}_{\mathrm{Ca}}$ channel in cardiac cells (Ohya et al., 2005). Because $\mathrm{BK}_{\mathrm{Ca}}$ was found here 
to also be a potential partner of this subunit of cytochrome $c$ oxidase (Table 1), it is possible that mitoBK $_{\mathrm{Ca}}$ can form a tripartite complex with these subunits in the heart.

mitoBK $_{\mathrm{Ca}}$ also participates in the regulation of the mPTP. Inhibition of its activity either by gene silencing in ischemia-reperfusion experiments (Singh et al., 2013) or by

pharmacological inhibition under basal conditions (Cheng et al., 2011) promotes the opening of mPTP. The current view on mPTP molecular composition supports ATP synthase dimers or ATP subunit $c$ as the core of mPTP surrounded by several regulatory subunits that include ANT (Giorgio et al., 2013; Halestrap and Richardson, 2015; Morciano et al., 2015; Izzo et al., 2016). That ATP synthase and ANT form a supercomplex (ATP synthasome) together with the inorganic phosphate carrier (PiC) is well established (Chen et al., 2004), although in rat cardiac mitochondria ANT can also be observed independently of ATP synthase (Nuskova et al., 2015). The proteomic data yielded several ATP synthase subunits as candidate partners of $\mathrm{BK}_{\mathrm{Ca}}$ as well as ANT and PiC. This novel information sets the background for future studies to learn whether $\mathrm{BK}_{\mathrm{Ca}}$ forms part of a megacomplex with the ATP synthase. As a first step, in this work, we chose to study the association of $\mathrm{BK}_{\mathrm{Ca}}$ with ANT (Figs. 5-7) (see below).

mitoBK $\mathrm{Ca}$ is a nuclear-encoded protein and thus, must be imported into mitochondria to fulfill its multiple functions. As will be discussed below, our data also gives initial clues about the mechanisms that could support mitoBK $_{\mathrm{Ca}}$ import.

\subsection{Tom22, a potential mitochondrial import mechanism for $\mathrm{BK}_{\mathrm{Ca}}$ channel}

A total of 8 proteins of the mitochondrial import system were found as potential partners of $\mathrm{BK}_{\mathrm{Ca}}$ (Table 1). Specifically, we found the receptor proteins Tom22 and Tom70, and the protein-conducting channel Tom 40 of the outer membrane TOM complex (Wenz et al., 2015); and Tim23, Tim16, GrpE1, and MPPA of the inner membrane Tim23-PAM classical presequence import pathway (Schulz et al., 2015). Although $\mathrm{BK}_{\mathrm{Ca}}$ lacks a presequence, there is precedence in the literature for atypical proteins (e.g. phosphate carrier) that only contain C-terminal or internal targeting sequences, like $\mathrm{BK}_{\mathrm{Ca}}$, that utilize the Tim23-PAM pathway (Schulz et al., 2015). Thus, $\mathrm{BK}_{\mathrm{Ca}}$ may be another example of this type of unconventional precursor proteins.

In this work, we scrutinized the association of the receptor protein Tom22 with $\mathrm{BK}_{\mathrm{Ca}}$ and $\mathrm{BK}_{\mathrm{Ca}}$-DEC. As mentioned before, the $\mathrm{C}$-terminal DEC splice insert favors $\mathrm{BK}_{\mathrm{Ca}}$ expression in mitochondria of adult cardiomyocytes making it a candidate for an import signal. Interestingly, both $\mathrm{BK}_{\mathrm{Ca}}$ isoforms (with or without $\mathrm{DEC}$ ) associated equally well with Tom22 (Fig. 2). Several explanations are possible: i) that the DEC insert is not essential for the association with Tom22 and that other regions in $\mathrm{BK}_{\mathrm{Ca}}$ are relevant, ii) that the $\mathrm{DEC}$ insert is substrate of another component of the import pathway, or iii) that $\mathrm{BK}_{\mathrm{Ca}}$ utilizes different import mechanisms depending on the cell type.

Our results also show that both $\mathrm{BK}_{\mathrm{Ca}}$ isoforms coexist with Tom22 in the "crude" and purified mitochondrial fractions (Fig. 3) demonstrating that both isoforms are able to be imported into mitochondria, and supporting the idea that their association can occur in this organelle. In co-expressing HEK293T cells, $\mathrm{BK}_{\mathrm{Ca}}$ isoforms were also present in the "crude" 
membrane fraction; this is expected as $\mathrm{BK}_{\mathrm{Ca}}$ can have multiple subcellular locations including the plasma membrane. Tom22 abundance in the cytosolic fraction (likely containing ribosomes) may be an indication of its synthesis at the time of cell harvesting in these cells, but the detection in "crude" membranes is at present enigmatic (Fig. 3E). Previous studies in expressing HeLa cells have shown faint signals in these fractions (Nakamura et al., 2004). The distribution of Tom 22 is in clear contrast with the sharp enrichment of ANT in mitochondrial fractions (Fig. 6) arguing against a deficiency in the fractionation protocol or a misstargeting effect due to overexpression. In any event, the results demonstrate beyond doubt that $\mathrm{BK}_{\mathrm{Ca}}$ can associate with Tom22 via its transmembrane segment and in doing so does not require the presence of the C-terminal DEC insert (Fig. 4). The association could be indirect via a yet to be discovered linking partner or direct protein-protein interaction between the two molecules. A simple picture in $\mathrm{BK}_{\mathrm{Ca}}$ import route based on these results and proteomic data can include the recognition of $\mathrm{BK}_{\mathrm{Ca}}$ precursor protein by Tom 22 and translocation via Tom 40 to reach the inner mitochondrial membrane (Fig. 8) perhaps driven by the Tim23-PAM complex. At present, we can not exclude the possibility that $\mathrm{BK}_{\mathrm{Ca}}$ association with Tom 22 could serve another function independent of its import. In fact, new non-assembled intermediate complexes have been recently discovered by proteomics between components of the Tom system (Tom40 and Tom22) and Porin 1 (the voltage dependent anion channel homolog in yeast) (Muller et al., 2016).

\section{3. $\mathrm{BK}_{\mathrm{Ca}}$ interaction with ANT}

We have demonstrated the novel interaction between $\mathrm{ANT}$ and $\mathrm{BK}_{\mathrm{Ca}}$ in co-expressing HEK293T cells (Figs. 5 and 7). As for Tom22, both $\mathrm{BK}_{\mathrm{Ca}}$ isoforms (with and without DEC) could associate with ANT; however, the presence of DEC sequence improved their association. The trend in subcellular distribution of $\mathrm{BK}_{\mathrm{Ca}}$ (with or without DEC) coexpressed with ANT including the relative abundance in the purified mitochondria fraction was similar to that observed with Tom22 (Figs. 3 and 6) indicating that its distribution to mitochondria was not biased by the co-expressed partner. At the time of harvesting of the cells, ANT was dramatically enriched in the purified mitochondria fraction and $\mathrm{BK}_{\mathrm{Ca}}$ though concentrated in the "crude" mitochondria fraction was also present in purified mitochondria (Fig. 6). Because ANT was so enriched in the purified mitochondria fraction, the likelihood that the interaction between the two proteins happens in the mitochondria is high. The fact that ANT resides in the inner mitochondrial membrane gives further support to the notion that $\mathrm{BK}_{\mathrm{Ca}}$ resides in this location as well (Fig. 8) (Xu et al., 2002). The association of $\mathrm{BK}_{\mathrm{Ca}}$ with $\mathrm{ANT}$ in the inner mitochondrial membrane could be in conjunction with the ATP synthasome as mentioned before (Fig. 8) or independent of it. In any case, the interaction of $\mathrm{BK}_{\mathrm{Ca}}$ and $\mathrm{ANT}$ discovered in this work takes place via the transmembrane domain of $\mathrm{BK}_{\mathrm{Ca}}$ (Fig. 7) either directly with ANT or via an unknown intermediary partner. Together our results open a new window to understand how $\mathrm{BK}_{\mathrm{Ca}}$ channel regulates the activity of mPTP inasmuch as ANT is a regulator of mPTP (Halestrap and Richardson, 2015). A functional coupling between $\mathrm{BK}_{\mathrm{Ca}}$ and $\mathrm{ANT}$ could be an additional factor in the complex regulation of $\mathrm{mPTP}$. 


\section{Conclusion}

The results from this work demonstrate the novel interactions of $\mathrm{BK}_{\mathrm{Ca}}$ with Tom22 and ANT, and provide a molecular framework to better understand the intricacies of $\mathrm{BK}_{\mathrm{Ca}}$ mitochondrial import mechanism and function.

\section{Acknowledgements}

This work was supported by the National Institutes of Health [grant HL107418 to LT, ES, RO].

\section{Abbreviations}

$\begin{array}{ll}\text { ANT } & \text { adenine nucleotide translocator } \\ \text { BK }_{\mathbf{C a}} & \text { large conductance voltage- and } \mathrm{Ca}^{2+} \text {-dependent } \mathrm{K}^{+} \text {channel } \\ \text { BK }_{\mathbf{C a}} \text {-DEC } & \mathrm{BK}_{\mathrm{Ca}} \text { containing DEC splice insert at the } \mathrm{C} \text {-terminus } \\ \text { Co-IP } & \text { co-immunoprecipitation } \\ \text { DEC } & \text { a } 50 \text { amino acid C-terminal } \mathrm{BK}_{\mathrm{Ca}} \text { splice insert } \\ \text { GST } & \text { glutathione } S \text {-transferase }\end{array}$

LC/MS/MS liquid chromatography, mass spectrometry in tandem

mAb monoclonal antibody

mitoBK $_{\mathbf{C a}}$ mitochondrial $\mathrm{BK}_{\mathrm{Ca}}$

mPTP mitochondrial permeability transition pore

pAb polyclonal antibody

Tom22 mitochondrial import receptor subunit Tom22

\section{References}

Aon MA, Cortassa S, Wei AC, Grunnet M, O'Rourke B. Energetic performance is improved by specific activation of $\mathrm{K}+$ fluxes through $\mathrm{K}(\mathrm{Ca})$ channels in heart mitochondria. Biochim.Biophys.Acta. 2010; 1797:71-80. [PubMed: 19744465]

Balderas E, Zhang J, Stefani E, Toro L. Mitochondrial BKCa channel. Front Physiol. 2015; 6:104. [PubMed: 25873902]

Bednarczyk P, Wieckowski MR, Broszkiewicz M, Skowronek K, Siemen D, Szewczyk A. Putative Structural and Functional Coupling of the Mitochondrial BK Channel to the Respiratory Chain. PLoS.One. 2013; 8:e68125. [PubMed: 23826369]

Chen C, Ko Y, Delannoy M, Ludtke SJ, Chiu W, Pedersen PL. Mitochondrial ATP synthasome: threedimensional structure by electron microscopy of the ATP synthase in complex formation with carriers for Pi and ADP/ATP. J.Biol.Chem. 2004; 279:31761-31768. [PubMed: 15166242]

Cheng Y, Gulbins E, Siemen D. Activation of the permeability transition pore by Bax via inhibition of the mitochondrial BK channel. Cell Physiol Biochem. 2011; 27:191-200. [PubMed: 21471707]

Dorner A, Olesch M, Giessen S, Pauschinger M, Schultheiss HP. Transcription of the adenine nucleotide translocase isoforms in various types of tissues in the rat. Biochim.Biophys.Acta. 1999; 1417:16-24. [PubMed: 10076031] 
Giorgio V, von SS, Antoniel M, Fabbro A, Fogolari F, Forte M, Glick GD, Petronilli V, Zoratti M, Szabo I, Lippe G, Bernardi P. Dimers of mitochondrial ATP synthase form the permeability transition pore. Proc Natl Acad Sci U S A. 2013; 110:5887-5892. [PubMed: 23530243]

Gorini G, Ponomareva O, Shores KS, Person MD, Harris RA, Mayfield RD. Dynamin-1 co-associates with native mouse brain BKCa channels: proteomics analysis of synaptic protein complexes. FEBS Lett. 2010; 584:845-851. [PubMed: 20114047]

Graham BH, Waymire KG, Cottrell B, Trounce IA, MacGregor GR, Wallace DC. A mouse model for mitochondrial myopathy and cardiomyopathy resulting from a deficiency in the heart/muscle isoform of the adenine nucleotide translocator. Nat.Genet. 1997; 16:226-234. [PubMed: 9207786]

Graham JM. Purification of a crude mitochondrial fraction by density-gradient centrifugation. Curr.Protoc.Cell Biol. 2001 Chapter 3, Unit.

Halestrap AP, Richardson AP. The mitochondrial permeability transition: a current perspective on its identity and role in ischaemia/reperfusion injury. J.Mol.Cell Cardiol. 2015; 78:129-141. [PubMed: 25179911]

Izzo V, Bravo-San Pedro JM, Sica V, Kroemer G, Galluzzi L. Mitochondrial Permeability Transition: New Findings and Persisting Uncertainties. Trends Cell Biol. 2016

Kathiresan T, Harvey M, Orchard S, Sakai Y, Sokolowski B. A protein interaction network for the large conductance $\mathrm{Ca}(2+)$-activated $\mathrm{K}(+)$ channel in the mouse cochlea. Mol.Cell Proteomics. 2009; 8:1972-1987. [PubMed: 19423573]

Li M, Zhang Z, Koh H, Lu R, Jiang Z, Alioua A, Garcia-Valdes J, Stefani E, Toro L. The beta1Subunit of the MaxiK Channel Associates with the Thromboxane A2 Receptor and Reduces Thromboxane A2 Functional Effects. J.Biol.Chem. 2013; 288:3668-3677. [PubMed: 23255603]

Liu Y, Chen XJ. Adenine nucleotide translocase, mitochondrial stress, and degenerative cell death. Oxid.Med.Cell Longev. 2013; 2013:146860. [PubMed: 23970947]

Ma D, Nakata T, Zhang G, Hoshi T, Li M, Shikano S. Differential trafficking of carboxyl isoforms of Ca2+-gated (Slo1) potassium channels. FEBS Lett. 2007; 581:1000-1008. [PubMed: 17303127]

Mayer A, Nargang FE, Neupert W, Lill R. MOM22 is a receptor for mitochondrial targeting sequences and cooperates with MOM19. EMBO J. 1995; 14:4204-4211. [PubMed: 7556061]

Meera P, Wallner M, Song M, Toro L. Large conductance voltage- and calcium-dependent K+ channel, a distinct member of voltage-dependent ion channels with seven $\mathrm{N}$-terminal transmembrane segments (S0-S6), an extracellular N terminus, and an intracellular(S9-S10) C terminus. Proc.Natl.Acad.Sci.U.S.A. 1997; 94:14066-14071. [PubMed: 9391153]

Misonou H, Menegola M, Buchwalder L, Park EW, Meredith A, Rhodes KJ, Aldrich RW, Trimmer JS. Immunolocalization of the Ca2+-activated $\mathrm{K}+$ channel Slo1 in axons and nerve terminals of mammalian brain and cultured neurons. J Comp Neurol. 2006; 496:289-302. [PubMed: 16566008]

Morciano G, Giorgi C, Bonora M, Punzetti S, Pavasini R, Wieckowski MR, Campo G, Pinton P. Molecular identity of the mitochondrial permeability transition pore and its role in ischemiareperfusion injury. J.Mol.Cell Cardiol. 2015; 78:142-153. [PubMed: 25172387]

Muller CS, Bildl W, Haupt A, Ellenrieder L, Becker T, Hunte C, Fakler B, Schulte U. Cryo-slicing Blue Native-Mass Spectrometry (csBN-MS), a Novel Technology for High Resolution Complexome Profiling. Mol.Cell Proteomics. 2016; 15:669-681. [PubMed: 26598645]

Nakamura Y, Suzuki H, Sakaguchi M, Mihara K. Targeting and assembly of rat mitochondrial translocase of outer membrane 22 (TOM22) into the TOM complex. J.Biol.Chem. 2004; 279:21223-21232. [PubMed: 14985332]

Nuskova H, Mracek T, Mikulova T, Vrbacky M, Kovarova N, Kovalcikova J, Pecina P, Houstek J. Mitochondrial ATP synthasome: Expression and structural interaction of its components. Biochem.Biophys.Res.Commun. 2015; 464:787-793. [PubMed: 26168732]

Ohya S, Kuwata Y, Sakamoto K, Muraki K, Imaizumi Y. Cardioprotective effects of estradiol include the activation of large-conductance $\mathrm{Ca}(2+)$-activated $\mathrm{K}(+)$ channels in cardiac mitochondria. Am.J.Physiol Heart Circ.Physiol. 2005; 289:H1635-H1642. [PubMed: 16113069]

Schulz C, Schendzielorz A, Rehling P. Unlocking the presequence import pathway. Trends Cell Biol. 2015; 25:265-275. [PubMed: 25542066] 
Singh H, Li M, Hall L, Chen S, Sukur S, Lu R, Caputo A, Meredith AL, Stefani E, Toro L. MaxiK channel interactome reveals its interaction with GABA transporter 3 and heat shock protein 60 in the mammalian brain. Neuroscience. 2016; 317:76-107. [PubMed: 26772433]

Singh H, Lu R, Bopassa JC, Meredith AL, Stefani E, Toro L. mitoBKCa is encoded by the Kcnma1 gene, and a splicing sequence defines its mitochondrial location. Proc Natl Acad Sci U S A. 2013; 110:10836-10841. [PubMed: 23754429]

Singh H, Lu R, Rodriguez PF, Wu Y, Bopassa JC, Stefani E, Toro L. Visualization and quantification of cardiac mitochondrial protein clusters with STED microscopy. Mitochondrion. 2012; 12:230 236. [PubMed: 21982778]

Singh H, Warburton S, Vondriska TM, Khakh BS. Proteomics to identify proteins interacting with P2X2 ligand-gated cation channels. J.Vis.Exp. 2009

Sokolowski B, Orchard S, Harvey M, Sridhar S, Sakai Y. Conserved BK channel-protein interactions reveal signals relevant to cell death and survival. PLoS.One. 2011; 6:e28532. [PubMed: 22174833]

Soltysinska E, Bentzen BH, Barthmes M, Hattel H, Thrush AB, Harper ME, Qvortrup K, Larsen FJ, Schiffer TA, Losa-Reyna J, Straubinger J, Kniess A, Thomsen MB, Bruggemann A, Fenske S, Biel M, Ruth P, Wahl-Schott C, Boushel RC, Olesen SP, Lukowski R. KCNMA1 encoded cardiac BK channels afford protection against ischemia reperfusion injury. PLoS.One. 2014; 9:e103402. [PubMed: 25072914]

Toro L, Li M, Zhang Z, Singh H, Wu Y, Stefani E. MaxiK channel and cell signalling. Pflugers Arch. 2013

Wallner M, Meera P, Ottolia M, Kaczorowski GJ, Latorre R, Garcia ML, Stefani E, Toro L. Characterization of and modulation by a beta-subunit of a human maxi $\mathrm{KCa}$ channel cloned from myometrium. Receptors.Channels. 1995; 3:185-199. [PubMed: 8821792]

Wenz LS, Opalinski L, Wiedemann N, Becker T. Cooperation of protein machineries in mitochondrial protein sorting. Biochim.Biophys.Acta. 2015; 1853:1119-1129. [PubMed: 25633533]

Xu W, Liu Y, Wang S, McDonald T, Van Eyk JE, Sidor A, O'Rourke B. Cytoprotective role of Ca2+activated K+ channels in the cardiac inner mitochondrial membrane. Science. 2002; 298:10291033. [PubMed: 12411707] 


\section{Highlights}

- 151 mitochondrial $\mathrm{BK}_{\mathrm{Ca}}$ channel protein partners are revealed by proteomics

- A molecular framework defining $\mathrm{BK}_{\mathrm{Ca}}$ mitochondrial protein relationships is provided

- $\quad$ Novel partners of $\mathrm{BK}_{\mathrm{Ca}}$ are Tom22 import protein and ANT nucleotide translocator

- $\quad \mathrm{BK}_{\mathrm{Ca}}$ interaction with $\mathrm{ANT}$ is enhanced by the 50 amino acid $\mathrm{BK}_{\mathrm{Ca}}$ splice insert, DEC

- $\quad$ The $\mathrm{BK}_{\mathrm{Ca}}$ transmembrane domain is required for the interaction with Tom 22 and ANT 

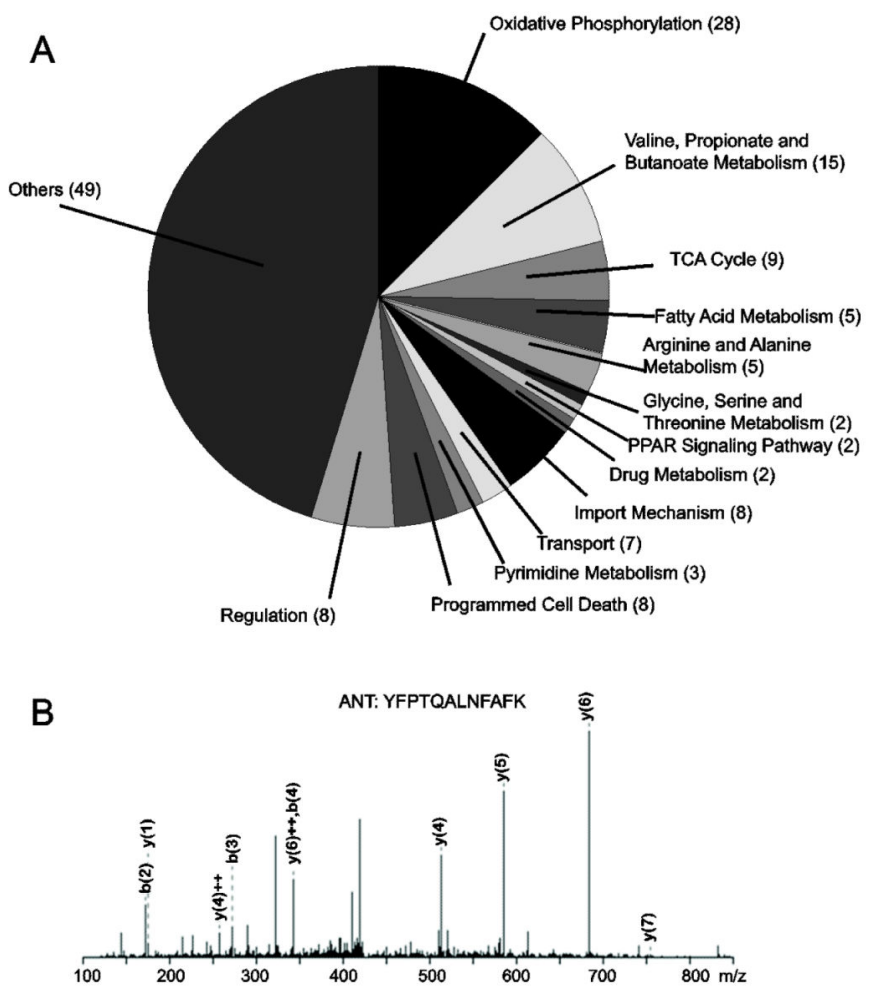

Figure 1. Mitochondrial partners of cardiac mitoBK $\mathrm{Ca}_{\text {a }}$ predict new channel functions (A) Gene ontology analysis using DAVID of mitochondrial $\mathrm{BK}_{\mathrm{Ca}}$ proteome revealed mitoBK $_{\mathrm{Ca}}$ potential involvement with 13 mitochondrial functions in the heart. Numbers in parenthesis correspond to the number of proteins allocated to each group. "Transport" group was entered manually. Isolation of $\mathrm{BK}_{\mathrm{Ca}}$ partners was performed using pull-down and immunoprecipitation with: 1) Recombinant GST-DEC and mitochondrial lysates of isolated cardiomyocytes, 2) Recombinant GST-DEC and whole-cardiomyocyte lysates, and 3) Monoclonal anti-BK $\mathrm{Ca}_{\mathrm{a}}$ antibody and lysates of Percoll-purified mitochondria from left ventricle. Controls included GST pull-down and IgG immunoprecipitation (see Methods). A total of 151 mitochondrial proteins with a score>21 were identified. (B) Example of mass spectrum of a peptide matching ANT. 


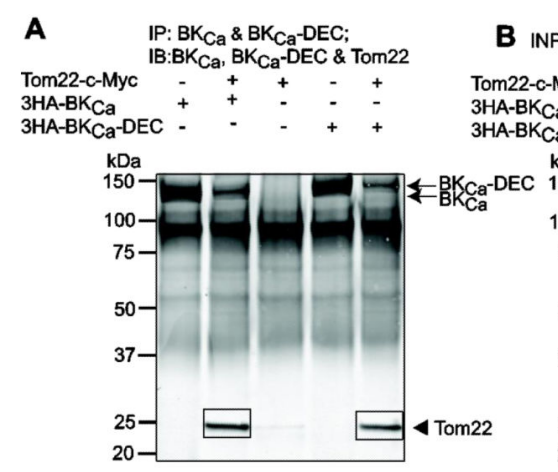

B INPUT: BKCa, BK $\mathrm{Ca}-\mathrm{DEC} \&$ Tom22

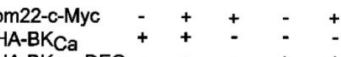

BKCa-DEC - - -
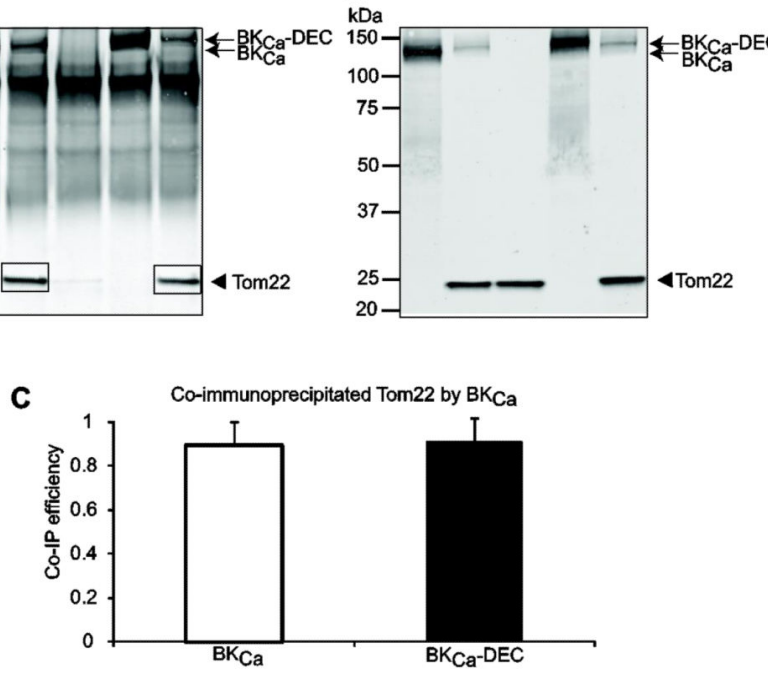

Figure 2. BK $\mathrm{Ca}$ interacts with Tom22 in HEK293T cells

Cells were co-transfected with $\mathrm{BK}_{\mathrm{Ca}}, \mathrm{BK}_{\mathrm{Ca}}$-DEC and Tom22 in different combinations (+, present; -, absent). Co-immunoprecipitated products are highlighted with squares. (A) Immunoblot demonstrating that $\mathrm{BK}_{\mathrm{Ca}}$ and $\mathrm{BK}_{\mathrm{Ca}}$-DEC pull down Tom22. $\mathrm{BK}_{\mathrm{Ca}}$ constructs were immunoprecipitated with anti-HA pAb and detected with anti-HA mAb (arrows) and co-immunoprecipitated Tom 22 was detected with anti-c-Myc mAb (arrowhead, squares).

Primary antibodies were incubated at the same time. (B) Immunoblot showing proper expression of $\mathrm{BK}_{\mathrm{Ca}}$ constructs (arrows) and Tom22 (arrowhead) in the input lysates. (C) $\mathrm{BK}_{\mathrm{Ca}}$ and $\mathrm{BK}_{\mathrm{Ca}}$-DEC efficiency in pulling down Tom 22 is similar ( $\mathrm{n}=3$ each). Co-IP efficiency was determined by first subtracting background signals, which in this case were negligible, and calculating the ratio of the band intensities of co-immunoprecipitated Tom22 (i.e. A, squares) to corresponding immunoprecipitated $\mathrm{BK}_{\mathrm{Ca}}$ constructs (i.e.. A, arrows), and normalized to Tom22 intensity in the corresponding input lysates (i.e. B, arrowhead). In this and following figures, image analysis was performed with MetaMorph Image Analysis Software (Molecular Devices). 
A
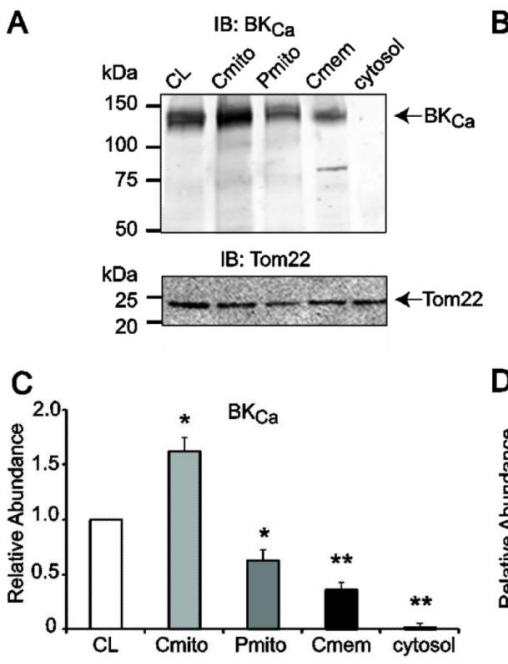

E

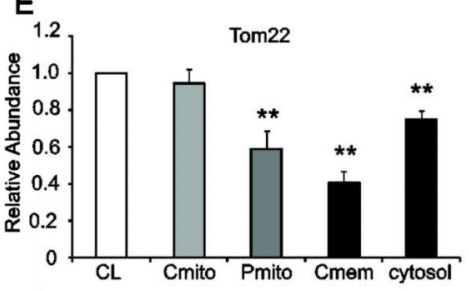

B

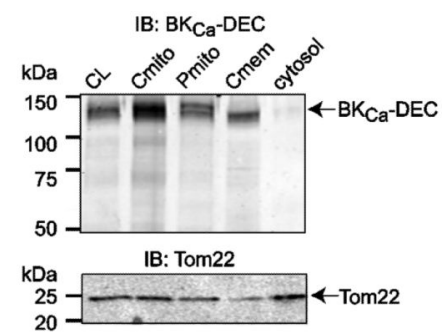

D

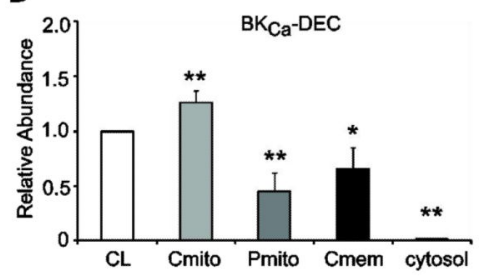

Figure 3. $\mathrm{BK}_{\mathrm{Ca}}$ and Tom22 are imported into mitochondria in HEK293T cells (A and B) Dually labeled immunoblots of $\mathrm{BK}_{\mathrm{Ca}}$ (A, top) or $\mathrm{BK}_{\mathrm{Ca}}-\mathrm{DEC}$ (B, top) coexpressed with Tom22 (bottom) in different cellular fractions: CL, whole cell lysate; Cmito, "crude" mitochondria; Pmito, Percoll-purified mitochondria; Cmem, "crude" membranes; cytosol, cytosolic fraction. $\mathrm{BK}_{\mathrm{Ca}}$ and Tom22 images were separated for clarity. In panel (A), $\mathrm{BK}_{\mathrm{Ca}}$ and Tom22 blots are from different experiments. $\mathrm{BK}_{\mathrm{Ca}}$ constructs were recognized with anti-HA mAb (upper panels); Tom22 was recognized with anti-c-Myc pAb (lower panels). (C-E) Mean values of $\mathrm{BK}_{\mathrm{Ca}}, \mathrm{BK}_{\mathrm{Ca}}$-DEC and Tom22 relative abundance in different cellular fractions show that $\mathrm{BK}_{\mathrm{Ca}}, \mathrm{BK}_{\mathrm{Ca}}-\mathrm{DEC}$ and Tom 22 were imported into "crude" and purified mitochondrial fractions, though not enriched. Values for Tom 22 were pooled from both $\mathrm{BK}_{\mathrm{Ca}}$ and $\mathrm{BK}_{\mathrm{Ca}}$-DEC experiments. *, $\mathrm{p}<0.05$ compared to CL. **, $\mathrm{p}<0.01$ compared to CL. $n=3$ independent experiments. 

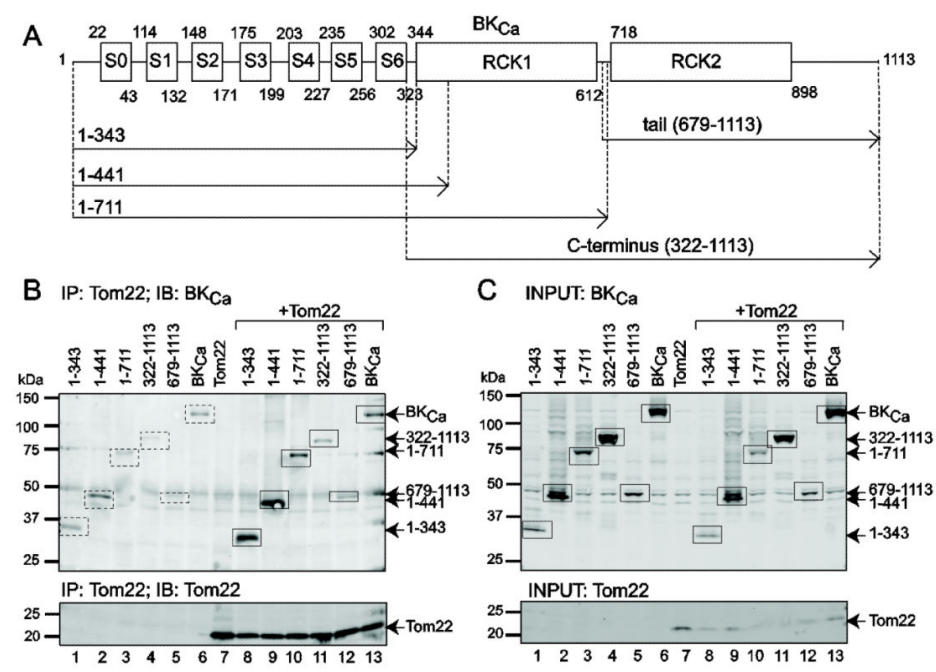

D

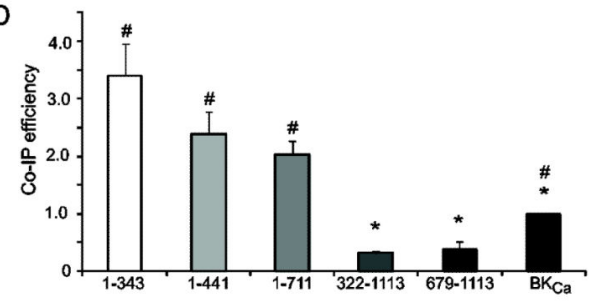

Figure 4. $\mathrm{BK}_{\mathrm{Ca}}$ channel transmembrane region interacts with Tom22

(A) Scheme of wild type $\mathrm{BK}_{\mathrm{Ca}}$ (1-1113) pore-forming a-subunit and different truncated proteins that were either expressed alone or co-expressed with Tom22. Numbers correspond to amino acid numbers in NCBI Accession No. U11058.2. S0-S6, transmembrane regions form the channel voltage sensor. Linker between S5-S6 forms the tetrameric channel pore region. Regulator of potassium conductance (RCK) 1 and 2 are $\mathrm{Ca}^{2+}$ sensors. (B) Dually labeled immunoblot for $\mathrm{BK}_{\mathrm{Ca}}$ (top) and Tom22 (bottom) showing the ability of Tom22 to co-immunoprecipitate different $\mathrm{BK}_{\mathrm{Ca}}$ channel regions (lanes 8-13, top). $\mathrm{BK}_{\mathrm{Ca}}$ and Tom22 images were separated for clarity. Lanes 1-7 are controls expressing $\mathrm{BK}_{\mathrm{Ca}}$ constructs or Tom22 alone. Squares and arrows mark the expected band sizes of each construct.

Background signals (dashed squares, lanes 1-7, top) were much lower than the signals of the co-immunoprecipitated $\mathrm{BK}_{\mathrm{Ca}}$ products (squares, lanes 8-13, top) and were subtracted to calculate Co-IP efficiency in (D). As control, the lower panel shows Tom22 successful immunoprecipitation. Tom 22 was immunoprecipitated with anti-DDK mAb. Coimmunoprecipitated $\mathrm{BK}_{\mathrm{Ca}}$ proteins were detected with anti-c-Myc $\mathrm{pAb}$, and Tom22 was detected with anti-DDK mAb. (C) Control immunoblot of input lysates of cells expressing different $\mathrm{BK}_{\mathrm{Ca}}$ regions (upper panel) and Tom22 (lower panel). $\mathrm{BK}_{\mathrm{Ca}}$ constructs were detected with anti-c-Myc pAb and Tom22 was detected with anti-DDK mAb. Squares and arrows mark the expected band sizes. (D) Tom22 efficiency in pulling down different $\mathrm{BK}_{\mathrm{Ca}}$ regions indicates that $\mathrm{BK}_{\mathrm{Ca}}$ channel interacts with Tom22 mainly through the transmembrane domain (construct 1-343). Co-IP efficiency was calculated after subtracting background signals and calculating the ratio of the band intensities of coimmunoprecipitated $\mathrm{BK}_{\mathrm{Ca}}$ constructs (i.e. $\mathrm{B}$, top, lanes 8-13, squares) to corresponding immunoprecipitated Tom22 (i.e. B, lower panel, lanes 8-13), and normalized to $\mathrm{BK}_{\mathrm{Ca}}$ 
construct intensities in the corresponding input lysates (i.e.. C, top, lanes 8-13). *, p $<0.05$ with respect to construct 1-343; \#, $\mathrm{p}<0.05$ with respect to the C-terminus (322-1113). 


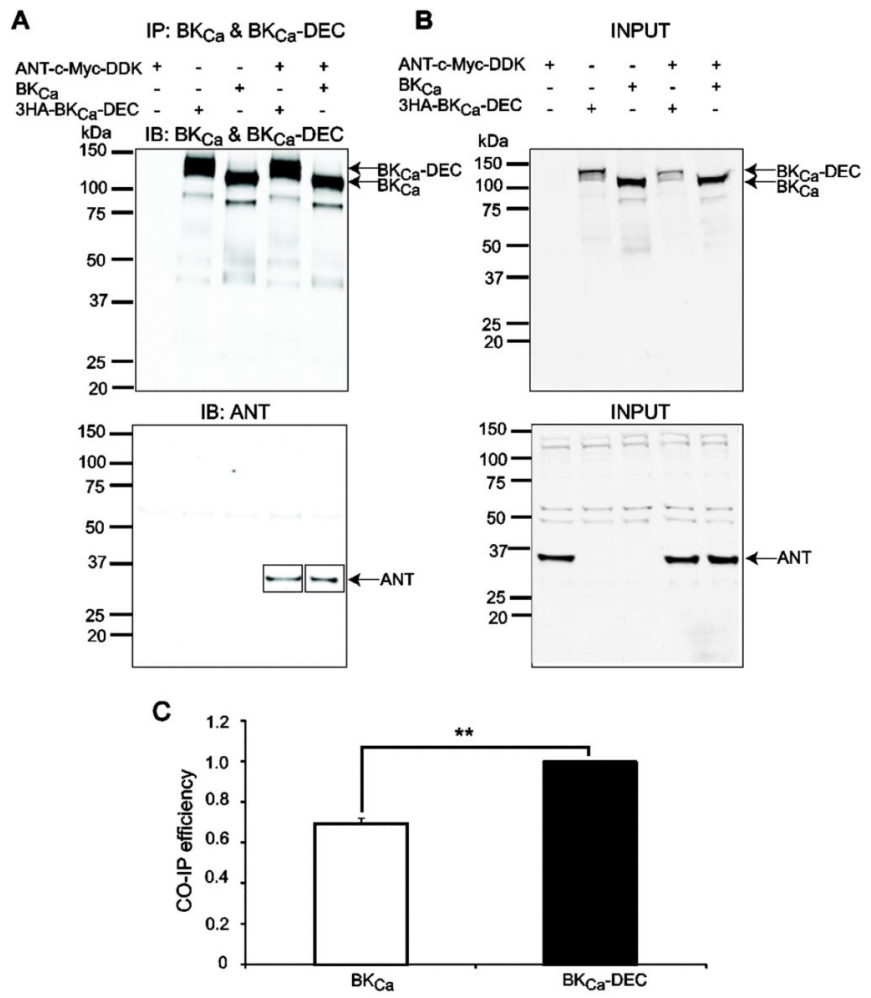

Figure 5. BK $\mathrm{Ca}$ interacts with ANT in HEK293T cells

Cells were co-transfected with $\mathrm{BK}_{\mathrm{Ca}}, \mathrm{BK}_{\mathrm{Ca}}$-DEC and ANT in different combinations (+, present; -, absent). (A) $\mathrm{BK}_{\mathrm{Ca}}$ and $\mathrm{BK}_{\mathrm{Ca}}$-DEC were immunoprecipitated with anti-BK $\mathrm{Ca}_{\mathrm{Ca}}$ $\mathrm{mAb}$ and detected with anti-BK $\mathrm{Ca}_{\mathrm{Ca}} \mathrm{pAb}$ (top panel); coimmunoprecipitated ANT was detected with anti-Flag pAb that recognizes the DDK epitope (lower panel, squares). Top and bottom panels are different blots using the same immunoprecipitation products. (B) Input lysates showing proper expression of $\mathrm{BK}_{\mathrm{Ca}}$ (top panel) and $\mathrm{ANT}$ (lower panel). $\mathrm{BK}_{\mathrm{Ca}}$ and $\mathrm{BK}_{\mathrm{Ca}}$-DEC were detected with anti-BK $\mathrm{Ca}$ pAb and ANT was detected with anti-Flag pAb. (C) Mean values of $\mathrm{BK}_{\mathrm{Ca}}$ and $\mathrm{BK}_{\mathrm{Ca}}$-DEC efficiency in pulling down ANT show that $\mathrm{BK}_{\mathrm{Ca}}$-DEC associates better with ANT by about $30 \%$. Co-immunoprecipitation efficiency was calculated as described in the legend to Figure 2 for Tom22. **, $\mathrm{p}<0.01, \mathrm{n}=3$ independent experiments. 
A

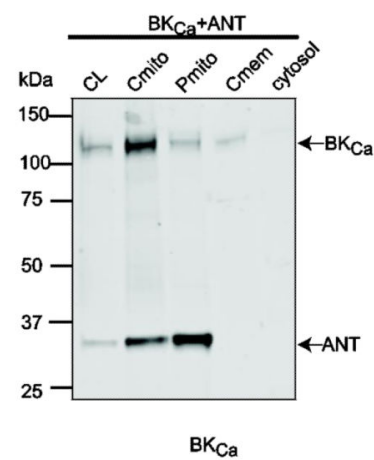

C
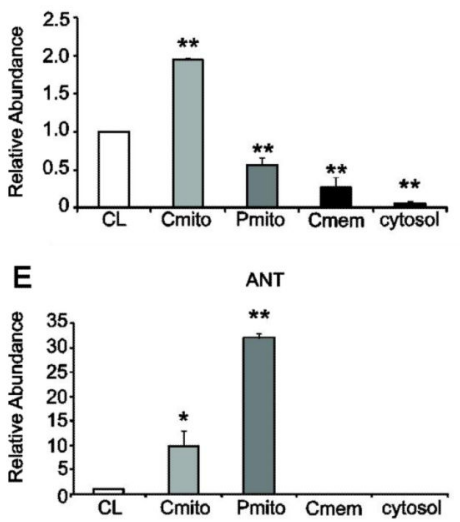

B
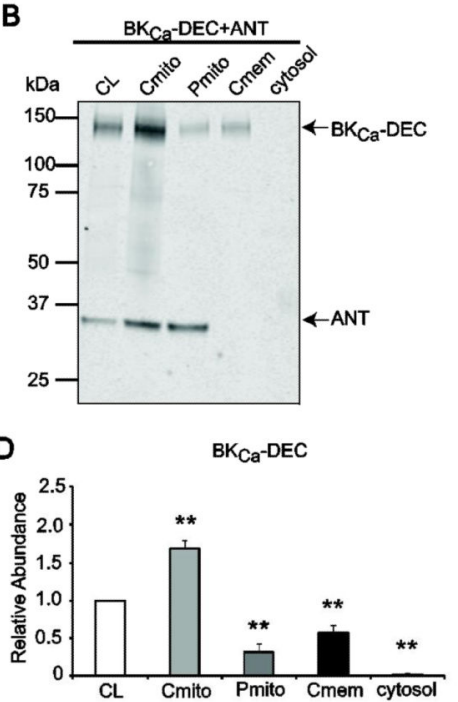

Figure 6. BK $\mathrm{Ca}_{\mathrm{a}}$ and $\mathrm{ANT}$ are imported into mitochondria of HEK293T cells $\mathrm{A}$ and $\mathrm{B}$, Dually labeled immunoblots of $\mathrm{BK}_{\mathrm{Ca}}(\mathrm{A})$ or $\mathrm{BK}_{\mathrm{Ca}}-\mathrm{DEC}(\mathrm{B})$ co-expressed with ANT show that the three constructs were imported into "crude" and purified mitochondria fractions. Note the enrichment of ANT in the purified mitochondria fraction. Labels are as in Fig. 3. BK $\mathrm{Ca}_{\mathrm{a}}$ was recognized with anti-HA mAb. ANT was recognized with anti-c-Myc pAb. $\mathrm{C}, \mathrm{D}$, and $\mathrm{E}$, Quantification of $\mathrm{BK}_{\mathrm{Ca}}, \mathrm{BK}_{\mathrm{Ca}}-\mathrm{DEC}$ and $\mathrm{ANT}$ relative abundance in different cellular fractions. *, $\mathrm{p}<0.05$ compared to $\mathrm{CL} ;{ }^{* *}, \mathrm{p}<0.01$ compared to $\mathrm{CL} . \mathrm{n}=3$ independent experiments. 

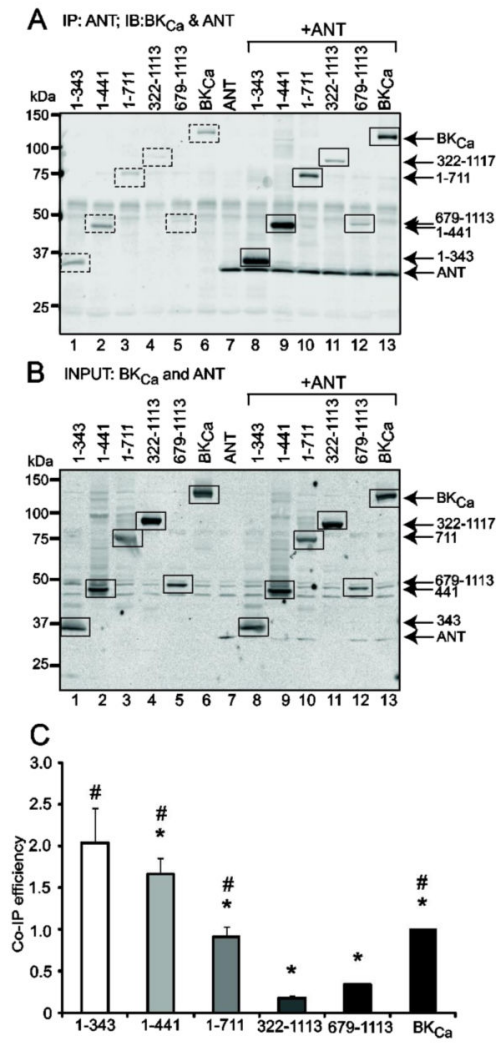

Figure 7. Molecular determinant of $\mathrm{BK}_{\mathrm{Ca}}$ channel interaction with ANT

Different regions of $\mathrm{BK}_{\mathrm{Ca}}$ and wild-type $\mathrm{BK}_{\mathrm{Ca}}$ (see scheme in Fig. 4A) were either expressed alone or co-expressed with ANT. (A) Dually labeled immunoblot shows that immunoprecipitated ANT pulled down wild-type and deletion $\mathrm{BK}_{\mathrm{Ca}}$ constructs (lanes 8-13) to different degrees. Squares and arrows mark the bands of the expected sizes. Dashed squares mark background signals, which were subtracted for the analysis in (C). ANT was immunoprecipitated with anti-DDK mAb. Coimmunoprecipitated $\mathrm{BK}_{\mathrm{Ca}}$ proteins and ANT were detected with anti-c-Myc pAb. (B) Control immunoblot of input lysates of cells expressing different $\mathrm{BK}_{\mathrm{Ca}}$ regions and ANT. (C) ANT efficiency in pulling different $\mathrm{BK}_{\mathrm{Ca}}$ constructs indicates that $\mathrm{BK}_{\mathrm{Ca}}$ channel interacts with ANT mainly through the transmembrane domain (construct 1-343). *, $\mathrm{p}<0.05$ with respect to construct 1-343; \#, $\mathrm{p}<0.05$ with respect to construct 322-1113. $\mathrm{n}=3$ independent experiments. 


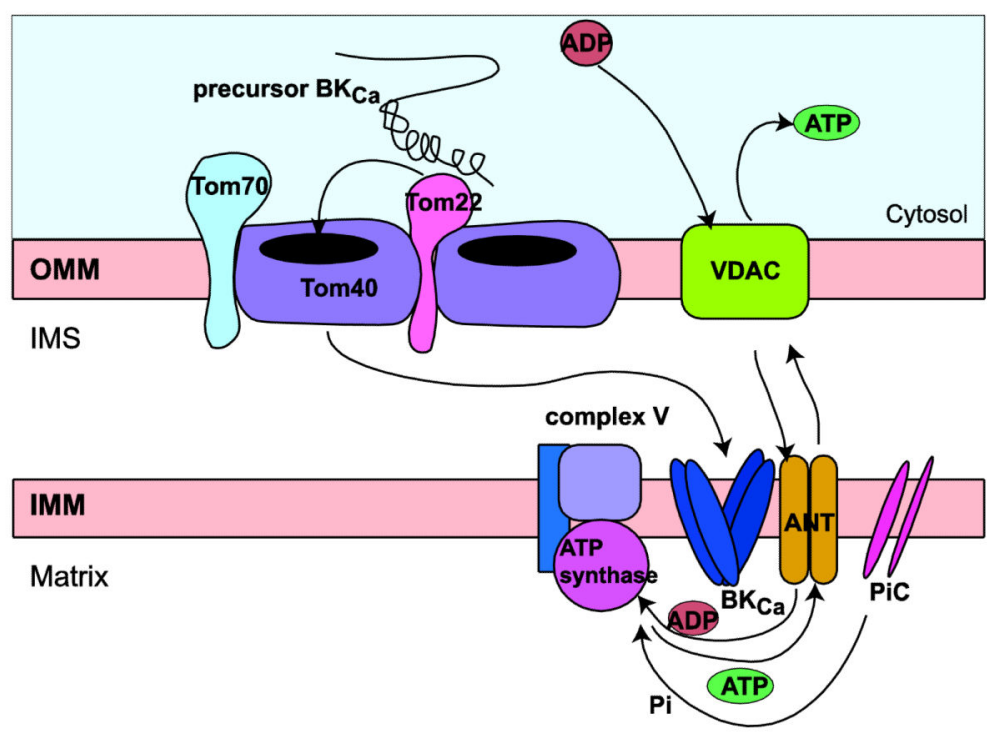

Figure 8. Scheme of potential mitoBK $\mathrm{Ca}_{\mathrm{a}}$ mport route and interactions in mitochondria Overall the results suggest that the precursor $\mathrm{BK}_{\mathrm{Ca}}$ could be recognized by Tom 22 in the outer mitochondrial membrane (OMM) and imported by Tom 40 to reach its final destination in the inner mitochondrial membrane (IMM). At the IMM, mitoBK $\mathrm{Ca}_{\mathrm{Ca}}$ interacts with ADP/ATP translocase (ANT). The interaction could be independent or in combination with known partners of ANT, e.g. the synthasome (ATP synthase and the phosphate carrier, $\mathrm{PiC}$ ), and implies a new role of mitoBK $_{\mathrm{Ca}}$ in mitochondrial metabolism. Of note, proteomic analysis (Table 1) points to the possibility that $\mathrm{BK}_{\mathrm{Ca}}$ may also interact with the voltagedependent anion channel VDAC, the ATP synthase and PiC. VDAC, allows ATP/ADP exchange with the intracellular milieu. IMS, intermembrane space. 
Table 1

$\mathrm{BK}_{\mathrm{Ca}}$ channel-interacting mitochondrial proteins identified by LC/MS/MS

\begin{tabular}{|c|c|c|c|c|}
\hline Proteins & Uniprot ID & Mass, Da & Score & Peptides \\
\hline \multicolumn{5}{|l|}{ Oxidative Phosphorylation } \\
\hline $\mathrm{NADH}$-ubiquinone oxidoreductase $75 \mathrm{kDa}$ subunit $(C, B)$ & NDUS1_RAT & 80331 & 785 & 18 \\
\hline ATP synthase protein $8(B)$ & ATP8_RAT & 7637 & 514 & 4 \\
\hline Succinate dehydrogenase [ubiquinone] flavoprotein subunit $(C)$ & DHSA_RAT & 72596 & 501 & 10 \\
\hline NADH dehydrogenase [ubiquinone] iron-sulfur protein $2(C)$ & NDUS2_RAT & 52927 & 268 & 8 \\
\hline Cytochrome c oxidase subunit 4 isoform $1(C)$ & COX41_RAT & 19559 & 266 & 10 \\
\hline ATP synthase-coupling factor $6^{(B)}$ & ATP5J_RAT & 12487 & 236 & 3 \\
\hline NADH dehydrogenase [ubiquinone] flavoprotein $2(B)$ & NDUV2_RAT & 27703 & 140 & 3 \\
\hline NADH dehydrogenase [ubiquinone] iron-sulfur protein $4(A, B)$ & NDUS4_RAT & 19785 & 135 & 4 \\
\hline Cytochrome b-c1 complex subunit Rieske $(B)$ & UCRI_RAT & 29712 & 128 & 7 \\
\hline $\begin{array}{l}\text { NADH dehydrogenase [ubiquinone] } 1 \text { alpha subcomplex } \\
\text { subunit } 10(C)\end{array}$ & NDUAA_RAT & 40753 & 127 & 5 \\
\hline ATP synthase subunit e ${ }^{(B)}$ & ATP5I_RAT & 8249 & 121 & 2 \\
\hline Cytochrome c oxidase subunit 7A2 $(A, B, C)$ & CX7A2_RAT & 9347 & 95 & 1 \\
\hline Succinate dehydrogenase [ubiquinone] iron-sulfur subunit $(A)$ & DHSB_RAT & 32607 & 95 & 3 \\
\hline Cytochrome c oxidase subunit $6 \mathrm{C}-2(B)$ & CX6C2_RAT & 8449 & 93 & 4 \\
\hline $\begin{array}{l}\text { NADH dehydrogenase [ubiquinone] } 1 \text { alpha subcomplex } \\
\text { subunit } 11(C)\end{array}$ & NDUAB_RAT & 15129 & 73 & 2 \\
\hline NADH dehydrogenase [ubiquinone] flavoprotein $3(B, C)$ & NDUV3_RAT & 11934 & 72 & 3 \\
\hline ATP synthase subunit epsilon $(B)$ & ATP5E_RAT & 5820 & 46 & 1 \\
\hline ATP synthase subunit d, mitochondrial $(A, C)$ & ATP5H_RAT & 18809 & 44 & 2 \\
\hline Cytochrome c oxidase subunit $1(B)$ & COX1_RAT & 56956 & 40 & 3 \\
\hline ATP synthase subunit a $((B),(C)$ & ATP6_RAT & 25034 & 38 & 1 \\
\hline Cytochrome $\mathrm{c}$ oxidase subunit $6 \mathrm{~A} 2(B)$ & CX6A2_RAT & 10594 & 30 & 1 \\
\hline Cytochrome b-c1 complex subunit $8(B)$ & QCR8_RAT & 9843 & 29 & 3 \\
\hline ATP synthase lipid-binding protein $(C)$ & AT5G1_RAT & 14463 & 29 & 2 \\
\hline NADH dehydrogenase [ubiquinone] iron-sulfur protein $6(B)$ & NDUS6_RAT & 12946 & 27 & 3 \\
\hline $\begin{array}{l}\text { NADH dehydrogenase [ubiquinone] } 1 \text { alpha subcomplex } \\
\text { assembly factor } 4(C)\end{array}$ & NDUF4_RAT & 20146 & 27 & 4 \\
\hline Cytochrome c oxidase subunit $6 \mathrm{C}-1(C)$ & CX6C1_RAT & 8547 & 26 & 1 \\
\hline ATP synthase subunit s $(C)$ & ATP5S_RAT & 23765 & 25 & 1 \\
\hline NADH-ubiquinone oxidoreductase chain $4(C)$ & NU4M_RAT & 51937 & 21 & 2 \\
\hline \multicolumn{5}{|l|}{ Valine, Propionate and Butanoate Metabolism } \\
\hline Trifunctional enzyme subunit alpha $(A)$ & ECHA_RAT & 83297 & 796 & 20 \\
\hline
\end{tabular}




\begin{tabular}{lllll}
\hline Proteins & Uniprot ID & Mass, Da & Score & Peptides \\
\hline 3-hydroxyacyl-CoA dehydrogenase type-2 $(A)$ & HCD2_RAT & 27343 & 125 & 4 \\
Short-chain specific acyl-CoA dehydrogenase $(A)$ & ACADS_RAT & 45022 & 87 & 1 \\
Malonyl-CoA decarboxylase $(C)$ & DCMC_RAT & 55298 & 81 & 5 \\
Isovaleryl-CoA dehydrogenase $(C)$ & IVD_RAT & 46862 & 64 & 2 \\
2-Oxoisovalerate dehydrogenase subunit alpha $(B, C)$ & ODBA_RAT & 50418 & 50 & 2 \\
Methylcrotonoyl-CoA carboxylase beta chain $(A, C)$ & MCCB_RAT & 61992 & 43 & 2 \\
Acyl-coenzyme A synthetase ACSM2 $(A)$ & ACSM2_RAT & 64617 & 41 & 3 \\
Propionyl-CoA carboxylase beta chain $(C)$ & PCCB_RAT & 59216 & 38 & 2 \\
Methylcrotonoyl-CoA carboxylase subunit alpha $(A, B, C)$ & MCCA_RAT & 79564 & 25 & 2 \\
3-Hydroxyisobutyrate dehydrogenase $(A)$ & 3HIDH_RAT & 35679 & 24 & 2 \\
3-Hydroxyisobutyrate dehydrogenase $(A)$ & 3HIDH_RAT & 35679 & 24 & 2 \\
Succinate-semialdehyde dehydrogenase $(B)$ & SSDH_RAT & 56723 & 23 & 1 \\
Propionyl-CoA carboxylase alpha chain $(A, C)$ & PCCA_RAT & 82198 & 23 & 5 \\
Dihydrolipoyl dehydrogenase $(B)$ & DLDH_RAT & 54574 & 22 & 3 \\
\hline
\end{tabular}

\section{TCA Cycle}

Pyruvate dehydrogenase E1 component subunit alpha, somatic form $(A)$

Malate dehydrogenase (B)

Succinyl-CoA ligase [GDP-forming] subunit alpha $(B)$

Dihydrolipoyllysine-residue acetyltransferase component of pyruvate dehydrogenase complex $(C)$

Fumarate hydratase $(A)$

Isocitrate dehydrogenase [NAD] subunit beta $(A)$

[Pyruvate dehydrogenase [lipoamide]] kinase isozyme $2(B)$

[Pyruvate dehydrogenase [lipoamide]] kinase isozyme $1(A)$

ODPA_RAT $43883 \quad 448 \quad 9$

Isocitrate dehydrogenase [NAD] subunit gamma $1(A)$

$\begin{array}{llll}\text { MDHM_RAT } & 36117 & 161 & 7 \\ \text { SUCA_RAT } & 36524 & 134 & 5 \\ \text { ODP2_RAT } & 67637 & 127 & 6 \\ & & & \\ \text { FUMH_RAT } & 54714 & 126 & 8 \\ \text { IDH3B_RAT } & 42612 & 125 & 10 \\ \text { PDK2_RAT } & 46304 & 105 & 7 \\ \text { PDK1_RAT } & 49392 & 88 & 6 \\ \text { IDHG1_RAT } & 43223 & 34 & 3\end{array}$

\section{Fatty Acid Metabolism}

Very long-chain specific acyl-CoA dehydrogenase $(C)$

$\begin{array}{llll}\text { ACADV_RAT } & 71047 & 801 & 16 \\ \text { CPT1B_RAT } & 89129 & 701 & 13 \\ \text { CPT2_RAT } & 74634 & 210 & 7 \\ \text { ACSL6_RAT } & 79156 & 52 & 4 \\ \text { PECI_RAT } & 43336 & 50 & 3\end{array}$

Carnitine O-palmitoyltransferase $1(A, B)$

Carnitine O-palmitoyltransferase $2(A, C)$

Long-chain-fatty-acid--CoA ligase $6(A, B)$

Peroxisomal 3,2-trans-enoyl-CoA isomerase $(A)$

\section{Arginine and Alanine Metabolism}

Glutamate dehydrogenase $1(C)$

DHE3_RAT $61719 \quad 190 \quad 12$

Amine oxidase [flavin-containing] A $(A, C)$

AOFA_RAT $60097 \quad 111 \quad 4$

Delta-1-pyrroline-5-carboxylate dehydrogenase ${ }^{(B)}$

AL4A1_RAT $62286 \quad 86 \quad 4$




\begin{tabular}{|c|c|c|c|c|}
\hline Proteins & Uniprot ID & Mass, Da & Score & Peptides \\
\hline Carbamoyl-phosphate synthase $(C)$ & CPSM_RAT & 165673 & 25 & 7 \\
\hline Amine oxidase [flavin-containing] B $(B)$ & AOFB_RAT & 59049 & 24 & 2 \\
\hline \multicolumn{5}{|l|}{ Glycine, Serine and Threonine Metabolism } \\
\hline 5-Aminolevulinate synthase, nonspecific $(B)$ & HEM1_RAT & 71830 & 28 & 5 \\
\hline Sarcosine dehydrogenase $(A)$ & SARDH_RAT & 102573 & 21 & 2 \\
\hline \multicolumn{5}{|l|}{ PPAR Signaling Pathway } \\
\hline Glycerol kinase $(A)$ & GLPK_RAT & 58238 & 37 & 2 \\
\hline Sterol 26-hydroxylase $(C)$ & CP27A_RAT & 60980 & 30 & 3 \\
\hline \multicolumn{5}{|l|}{ Drug Metabolism } \\
\hline Glutathione $\mathrm{S}$-transferase $\mathrm{P}(A)$ & GSTP1_RAT & 23652 & 80 & 2 \\
\hline Glutathione S-transferase kappa $1(A)$ & GSTK1_RAT & 25590 & 27 & 2 \\
\hline \multicolumn{5}{|l|}{ Import Mechanism } \\
\hline Sorting and assembly machinery component 50 homolog $(C)$ & SAM50_RAT & 52384 & 372 & 12 \\
\hline GrpE protein homolog $1(B, D)$ & GRPE1_RAT & 24510 & 303 & 9 \\
\hline Mitochondrial-processing peptidase subunit alpha $(C)$ & MPPA_RAT & 59083 & 165 & 7 \\
\hline $\begin{array}{l}\text { Mitochondrial import inner membrane translocase subunit } \\
\text { TIM16 }(C)\end{array}$ & TIM16_RAT & 13722 & 103 & 1 \\
\hline Mitochondrial import receptor subunit TOM22 (B) & TOM22_RAT & 15481 & 94 & 1 \\
\hline $\begin{array}{l}\text { Mitochondrial import inner membrane translocase subunit } \\
\text { Tim23 }(C)\end{array}$ & TIM23_RAT & 22064 & 45 & 2 \\
\hline Mitochondrial import receptor subunit TOM40 $(A)$ & TOM40_RAT & 38294 & 35 & 2 \\
\hline Mitochondrial import receptor subunit TOM70 $(A)$ & TOM70_RAT & 68143 & 24 & 2 \\
\hline \multicolumn{5}{|l|}{ Transport (Channels and Carriers)* } \\
\hline Voltage-dependent anion-selective channel protein $1(A, C)$ & VDAC1_RAT & 30851 & 173 & 4 \\
\hline Phosphate carrier protein $(C)$ & MPCP_RAT & 39876 & 50 & 2 \\
\hline ADP/ATP translocase $2((B), E)$ & ADT2_RAT & 33108 & 43 & 2 \\
\hline ATP-binding cassette sub-family B member $7(C)$ & ABCB7_RAT & 82848 & 40 & 6 \\
\hline Voltage-dependent anion-selective channel protein $3(C)$ & VDAC3_RAT & 31178 & 32 & 2 \\
\hline Tricarboxylate transport protein $(B)$ & TXTP_RAT & 34156 & 24 & 4 \\
\hline Calcium-binding mitochondrial carrier protein SCaMC-2 $(C)$ & SCMC2_RAT & 53060 & 24 & 1 \\
\hline \multicolumn{5}{|l|}{ Pyrimidine Metabolism } \\
\hline GTP:AMP phosphotransferase $(C)$ & KAD3_RAT & 25479 & 98 & 3 \\
\hline Thymidylate synthase $(A)$ & TYSY_RAT & 35280 & 30 & 2 \\
\hline Thioredoxin reductase $2(A)$ & TRXR2_RAT & 57167 & 23 & 4 \\
\hline
\end{tabular}

Programmed Cell Death 


\begin{tabular}{|c|c|c|c|c|}
\hline Proteins & Uniprot ID & Mass, Da & Score & Peptides \\
\hline Apoptosis-inducing factor $1(C)$ & AIFM1_RAT & 66966 & 133 & 6 \\
\hline Dynamin-like $120 \mathrm{kDa}$ protein $(A)$ & OPA1_RAT & 111751 & 115 & 5 \\
\hline Mitochondrial fission 1 protein $(C)$ & FIS1_RAT & 17041 & 43 & 1 \\
\hline Dynamin-1-like protein $(A)$ & DNM1L_RAT & 84369 & 37 & 4 \\
\hline Chaperone activity of bc 1 complex-like $(C)$ & ADCK3_RAT & 72750 & 24 & 2 \\
\hline Receptor-interacting serine/threonine-protein kinase $3(A)$ & RIPK3_RAT & 52715 & 24 & 3 \\
\hline Superoxide dismutase ( $A, B, C$ ) & SODM_RAT & 24887 & 24 & 1 \\
\hline Protein TBRG4 $(A)$ & TBRG4_RAT & 71592 & 24 & 4 \\
\hline \multicolumn{5}{|l|}{ Regulation } \\
\hline LETM1 and EF-hand domain-containing protein $1(C)$ & LETM1_RAT & 83635 & 203 & 10 \\
\hline Elongation factor $\mathrm{G}(C)$ & EFGM_RAT & 84089 & 96 & 5 \\
\hline Mitofusin-2 $(C)$ & MFN2_RAT & 86809 & 37 & 4 \\
\hline Thioredoxin-dependent peroxide reductase $(A, B)$ & PRDX3_RAT & 28563 & 30 & 1 \\
\hline Lon protease homolog, mitochondrial $(B, C)$ & LONM_RAT & 106296 & 27 & 9 \\
\hline Single-stranded DNA-binding protein $(A)$ & SSBP_RAT & 17444 & 25 & 1 \\
\hline DNA polymerase subunit gamma-1 $(A)$ & DPOG1_RAT & 137909 & 23 & 3 \\
\hline \multicolumn{5}{|l|}{ Others $^{\#}$} \\
\hline Stress-70 protein $(C)$ & GRP75_RAT & 74097 & 1023 & 22 \\
\hline $\begin{array}{l}\text { ATP-dependent Clp protease ATP-binding subunit clpX-like } \\
(C)\end{array}$ & CLPX_RAT & 69963 & 288 & 9 \\
\hline Acyl-coenzyme A thioesterase $2(B)$ & ACOT2_RAT & 49955 & 178 & 5 \\
\hline Electron transfer flavoprotein subunit beta $(B)$ & ETFB_RAT & 27898 & 145 & 8 \\
\hline A-kinase anchor protein $1(C)$ & AKAP1_RAT & 92660 & 95 & 2 \\
\hline Up-regulated during skeletal muscle growth protein $5(A, B)$ & USMG5_RAT & 6460 & 92 & 2 \\
\hline Cytochrome b5 type $\mathrm{B}(A, B)$ & CYB5B_RAT & 16312 & 89 & 3 \\
\hline $\begin{array}{l}\text { [Pyruvate dehydrogenase [acetyl-transferring]]-phosphatase } 1 \\
(C)\end{array}$ & PDP1_RAT & 61739 & 68 & 1 \\
\hline Nucleoside diphosphate-linked moiety X motif $19(A)$ & NUD19_RAT & 40426 & 68 & 1 \\
\hline Growth hormone-inducible transmembrane protein $(A)$ & GHITM_RAT & 37324 & 66 & 2 \\
\hline $\begin{array}{l}\text { [3-methyl-2-oxobutanoate dehydrogenase [lipoamide]] kinase } \\
\text { (C) }\end{array}$ & BCKD_RAT & 46673 & 63 & 1 \\
\hline Iron-sulfur cluster assembly 1 homolog $(C)$ & ISCA1_RAT & 14311 & 57 & 2 \\
\hline ATPase family AAA domain-containing protein $3(A, B)$ & ATAD3_RAT & 66889 & 53 & 8 \\
\hline Peroxiredoxin-5 $(B)$ & PRDX5_RAT & 22507 & 53 & 1 \\
\hline $\operatorname{Delta}(3,5)$-Delta(2,4)-dienoyl-CoA isomerase $(A)$ & ECH1_RAT & 36491 & 52 & 2 \\
\hline Tyrosyl-tRNA synthetase, mitochondrial $(C)$ & SYYM_RAT & 52936 & 51 & 1 \\
\hline Quinone oxidoreductase-like protein $2(C)$ & QORL2_RAT & 38095 & 47 & 2 \\
\hline
\end{tabular}




\begin{tabular}{|c|c|c|c|c|}
\hline Proteins & Uniprot ID & Mass, Da & Score & Peptides \\
\hline Uncharacterized protein $\mathrm{C}$ 2orf47 homolog $(A, C)$ & CB047_RAT & 33411 & 39 & 1 \\
\hline Transmembrane protein $126 \mathrm{~A}(A, C)$ & T126A_RAT & 21758 & 39 & 3 \\
\hline CDGSH iron-sulfur domain-containing protein $1(A)$ & CISD1_RAT & 12260 & 37 & 1 \\
\hline Brain protein $44(B)$ & BR44_RAT & 14306 & 36 & 2 \\
\hline Coiled-coil domain-containing protein 90B $(A)$ & CC90B_RAT & 29895 & 34 & 3 \\
\hline ES1 protein homolog $(A, B)$ & ES1_RAT & 28497 & 34 & 2 \\
\hline Electron transfer flavoprotein-ubiquinone oxidoreductase $(C)$ & ETFD_RAT & 69010 & 32 & 5 \\
\hline Glycerol-3-phosphate acyltransferase $1(C)$ & GPAT1_RAT & 94568 & 32 & 2 \\
\hline $39 \mathrm{~S}$ ribosomal protein $\mathrm{L} 14(C)$ & RM14_RAT & 16017 & 32 & 2 \\
\hline $\begin{array}{l}\text { Fumarylacetoacetate hydrolase domain-containing protein } 1 \\
\text { (C) }\end{array}$ & FAHD1_RAT & 24750 & 31 & 1 \\
\hline Kynurenine/alpha-aminoadipate aminotransferase $(A, B, C)$ & AADAT_RAT & 48096 & 29 & 2 \\
\hline GTP-binding protein Rhes $(B)$ & RHES_RAT & 30576 & 28 & 2 \\
\hline Oxidation resistance protein $1(C)$ & OXR1_RAT & 93209 & 27 & 3 \\
\hline Enoyl-CoA hydratase domain-containing protein $3(B)$ & ECHD3_RAT & 32650 & 27 & 4 \\
\hline Protein $\operatorname{Mpv17}(C)$ & MPV17_RAT & 19842 & 27 & 1 \\
\hline Surfeit locus protein $1(C)$ & SURF1_RAT & 35060 & 26 & 3 \\
\hline RRP15-like protein $(A)$ & RRP15_RAT & 31078 & 26 & 3 \\
\hline Serine/threonine-protein phosphatase PGAM5 $(A)$ & PGAM5_RAT & 32269 & 25 & 1 \\
\hline UPF0629 protein C17orf42 homolog $(C)$ & CQ042_RAT & 41911 & 25 & 1 \\
\hline Leucine-rich PPR motif-containing protein $(C)$ & LPPRC_RAT & 157808 & 24 & 9 \\
\hline Stomatin-like protein $2(A, B)$ & STML2_RAT & 38504 & 24 & 1 \\
\hline $\begin{array}{l}\text { Growth arrest and DNA damage-inducible proteins-interacting } \\
\text { protein } 1(A)\end{array}$ & G45IP_RAT & 26565 & 23 & 7 \\
\hline Probable Xaa-Pro aminopeptidase $3(A)$ & XPP3_RAT & 57103 & 23 & 2 \\
\hline NLR family member X1 $(A)$ & NLRX1_RAT & 108548 & 22 & 4 \\
\hline Beta-lactamase-like protein $2(B)$ & LACB2_RAT & 32749 & 22 & 1 \\
\hline Translational activator of cytochrome c oxidase $1(A)$ & TACO1_RAT & 33190 & 22 & 5 \\
\hline Pyruvate carboxylase $(A, C)$ & PYC_RAT & 130436 & 22 & 4 \\
\hline Kinesin-like protein KIF1B $(A)$ & KIF1B_RAT & 205411 & 21 & 7 \\
\hline Protein FAM54B $(A)$ & FA54B_RAT & 32166 & 21 & 2 \\
\hline $39 \mathrm{~S}$ ribosomal protein $\mathrm{L} 38(C)$ & RM38_RAT & 45095 & 21 & 1 \\
\hline Aldehyde dehydrogenase $\mathrm{X}^{(B)}$ & AL1B1_RAT & 58102 & 21 & 1 \\
\hline Patatin-like phospholipase domain-containing protein $7(A)$ & PLPL7_RAT & 151240 & 21 & 1 \\
\hline
\end{tabular}

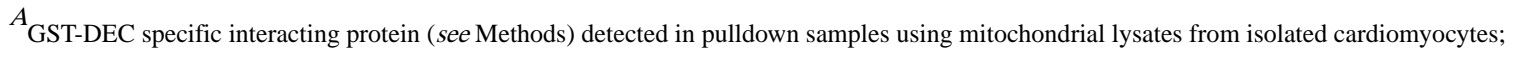

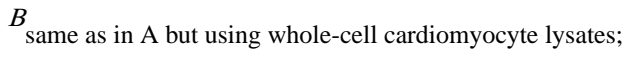




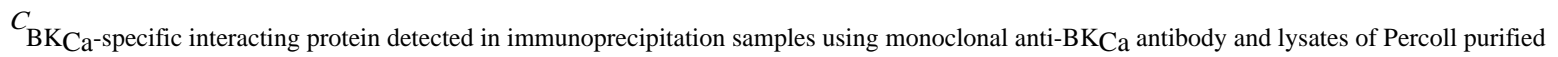
mitochondria from left ventricle (see Methods).

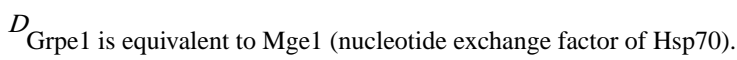

(E) Peptides found (TAVAPIE, YFPTQALNFAFK) are identical in ADP/ATP translocase 1.

\# Some proteins were re-assigned manually to known functions according to UniProt.

* Proteins in "Transport" group were assigned manually. The number of peptides correspond to the highest score of each identified protein. 
Table 2

$\mathrm{BK}_{\mathrm{Ca}}$ channel-interacting proteins from identified by LC/MS/MS.

\begin{tabular}{|c|c|c|c|c|}
\hline Proteins & Uniprot ID & Mass, Da & Score & Peptides \\
\hline \multicolumn{5}{|l|}{ Endoplasmic Reticulum } \\
\hline Extended synaptotagmin-1 $(B, C)$ & ESYT1_RAT & 121369 & 139 & 6 \\
\hline $78 \mathrm{kDa}$ glucose-regulated protein $(B, C)$ & GRP78_RAT & 72473 & 136 & 4 \\
\hline Sarcoplasmic/endoplasmic reticulum calcium ATPase $1(A, B, C)$ & AT2A1_RAT & 110707 & 65 & 2 \\
\hline Carnitine O-acetyltransferase $(A, C)$ & CACP_RAT & 71211 & 65 & 4 \\
\hline Erlin-2 $\left({ }^{B}\right)$ & ERLN2_RAT & 37915 & 62 & 4 \\
\hline Elongation factor 1-gamma $(A, B)$ & EF1G_RAT & 50371 & 57 & 3 \\
\hline Serpin $\mathrm{H} 1(B)$ & SERPH_RAT & 46602 & 51 & 3 \\
\hline Cytochrome P450 2C11 $\left({ }^{A}\right)$ & CP2CB_RAT & 57658 & 39 & 3 \\
\hline Calreticulin $\left({ }^{A}\right)$ & CALR_RAT & 48137 & 38 & 1 \\
\hline $\begin{array}{l}\text { Dolichyl-diphosphooligosaccharide--protein } \\
\text { glycosyltransferase subunit } 2(B)\end{array}$ & RPN2_RAT & 69149 & 37 & 2 \\
\hline Sterol regulatory element-binding protein $2(A, C)$ & SRBP2_RAT & 124096 & 37 & 2 \\
\hline Calnexin $(A, B)$ & CALX_RAT & 67612 & 36 & 2 \\
\hline ORM1-like protein $3(C)$ & ORML3_RAT & 17451 & 34 & 1 \\
\hline Reticulon-4 $(C)$ & RTN4_RAT & 126766 & 33 & 3 \\
\hline Antigen peptide transporter $2\left({ }^{A}\right)$ & TAP2_RAT & 78063 & 32 & 3 \\
\hline Procollagen-lysine,2-oxoglutarate 5-dioxygenase $3\left({ }^{A}\right)$ & PLOD3_RAT & 85577 & 31 & 2 \\
\hline Cytochrome P450 2A2 $\left({ }^{A}\right)$ & CP2A2_RAT & 56480 & 30 & 3 \\
\hline $\begin{array}{l}3 \text { beta-hydroxysteroid dehydrogenase/Delta 5-->4- } \\
\text { isomerase type } 2\left({ }^{A}\right)\end{array}$ & 3BHS2_RAT & 42592 & 29 & 1 \\
\hline HCLS1-associated protein X-1 $(C)$ & HAX1_RAT & 31429 & 29 & 2 \\
\hline Inositol 1,4,5-trisphosphate receptor type $1(A, C)$ & ITPR1_RAT & 316486 & 29 & 3 \\
\hline Transmembrane protein $214\left({ }^{A}\right)$ & TM214_RAT & 77486 & 29 & 2 \\
\hline $\begin{array}{l}\text { Sterol-4-alpha-carboxylate 3-dehydrogenase, } \\
\text { decarboxylating }\left({ }^{A}\right)\end{array}$ & NSDHL_RAT & 40671 & 27 & 1 \\
\hline Squalene synthase ( ${ }^{A}$ ) & FDFT_RAT & 48703 & 26 & 1 \\
\hline Protein ERGIC-53-like $\left({ }^{A}\right)$ & LMA1L_RAT & 56571 & 26 & 2 \\
\hline BET1 homolog $\left({ }^{A}\right)$ & BET1_RAT & 13336 & 26 & 2 \\
\hline Protein ERGIC-53 $(B)$ & LMAN1_RAT & 58206 & 26 & 1 \\
\hline Cytochrome P450 3A1 $(B)$ & CP3A1_RAT & 58222 & 26 & 1 \\
\hline Carboxylesterase $3\left({ }^{B}\right)$ & CES3_RAT & 62393 & 25 & 2 \\
\hline Choline-phosphate cytidylyltransferase B $\left({ }^{B}\right)$ & PCY1B_RAT & 42159 & 25 & 1 \\
\hline Reticulocalbin-2 $\left({ }^{A}\right)$ & RCN2_RAT & 37410 & 25 & 2 \\
\hline Cytochrome P450 2C12, female-specific ( $C$ ) & CP2CC_RAT & 56453 & 24 & 1 \\
\hline
\end{tabular}




\begin{tabular}{|c|c|c|c|c|}
\hline Proteins & Uniprot ID & Mass, Da & Score & Peptides \\
\hline Cytochrome P450 2E1 ( $C$ ) & CP2E1_RAT & 56990 & 24 & 2 \\
\hline Multiple coagulation factor deficiency protein 2 homolog $\left({ }^{A}\right)$ & MCFD2_RAT & 16252 & 24 & 1 \\
\hline Thrombospondin-4 $\left({ }^{A}\right)$ & TSP4_RAT & 110882 & 24 & 1 \\
\hline DnaJ homolog subfamily $\mathrm{C}$ member $3(A, C)$ & DNJC3_RAT & 57981 & 24 & 3 \\
\hline Lipase maturation factor $2\left({ }^{A}\right)$ & LMF2_RAT & 80431 & 23 & 1 \\
\hline Phosphatidylinositol-glycan biosynthesis class $\mathrm{W}$ protein $(A, C)$ & PIGW_RAT & 57205 & 23 & 1 \\
\hline LDLR chaperone $\operatorname{MESD}\left({ }^{A}\right)$ & MESD_RAT & 25314 & 23 & 1 \\
\hline Uncharacterized glycosyltransferase AER61 $(C)$ & AER61_RAT & 62340 & 23 & 2 \\
\hline $\begin{array}{l}\text { Inhibitor of nuclear factor kappa-B kinase-interacting } \\
\text { protein }(B)\end{array}$ & IKIP_RAT & 42391 & 22 & 3 \\
\hline Sphingosine-1-phosphate lyase $1\left({ }^{A}\right)$ & SGPL1_RAT & 64287 & 22 & 4 \\
\hline Dehydrogenase/reductase SDR family member 7B $\left({ }^{C}\right)$ & DRS7B_RAT & 35662 & 22 & 2 \\
\hline UDP-glucose:glycoprotein glucosyltransferase $1\left({ }^{C}\right)$ & UGGG1_RAT & 177061 & 22 & 3 \\
\hline Poly [ADP-ribose] polymerase $16(C)$ & PAR16_RAT & 37088 & 21 & 2 \\
\hline \multicolumn{5}{|l|}{ Golgi } \\
\hline Ras-related protein Rab-10 $(C)$ & RAB10_RAT & 23072 & 102 & 2 \\
\hline Ras-related protein Rab-1A ( $\left.{ }^{C}\right)$ & RAB1A_RAT & 22891 & 67 & 2 \\
\hline Calcium-transporting ATPase type $2 \mathrm{C}$ member $1(B)$ & AT2C1_RAT & 101519 & 39 & 2 \\
\hline Nucleobindin-2 $\left(A_{\text {) }}\right.$ & NUCB2_RAT & 50173 & 39 & 1 \\
\hline Phosphofurin acidic cluster sorting protein $1(A, B)$ & PACS1_RAT & 105034 & 32 & 2 \\
\hline Golgin subfamily A member $2\left({ }^{A}\right)$ & GOGA2_RAT & 113232 & 31 & 7 \\
\hline Caveolin-3 $(A), B$ ) & CAV3_RAT & 17904 & 31 & 1 \\
\hline $\begin{array}{l}\text { CMP-N-acetylneuraminate-beta-1,4-galactoside alpha-2,3- } \\
\text { sialyltransferase }(A)\end{array}$ & SIAT6_RAT & 42340 & 29 & 3 \\
\hline $\begin{array}{l}\text { Protein O-linked-mannose beta-1,2-N- } \\
\text { acetylglucosaminyltransferase } 1\left({ }^{A}\right)\end{array}$ & PMGT1_RAT & 75670 & 28 & 1 \\
\hline $\begin{array}{l}\text { Alpha-1,3-mannosyl-glycoprotein 2-beta-N- } \\
\text { acetylglucosaminyltransferase }(A)\end{array}$ & MGAT1_RAT & 51839 & 27 & 1 \\
\hline Myomegalin $(A, B, C)$ & MYOME_RAT & 263193 & 26 & 7 \\
\hline Vacuolar protein sorting-associated protein $54(B)$ & VPS54_RAT & 109913 & 24 & 3 \\
\hline Acid phosphatase-like protein $2(C)$ & ACPL2_RAT & 55664 & 24 & 1 \\
\hline Golgi phosphoprotein 3-like $\left({ }^{A}\right)$ & GLP3L_RAT & 33072 & 23 & 3 \\
\hline Carbohydrate sulfotransferase $11(B)$ & CHSTB_RAT & 42112 & 23 & 3 \\
\hline $\begin{array}{l}\text { Beta-1,4-mannosyl-glycoprotein 4-beta-N- } \\
\text { acetylglucosaminyltransferase }\left({ }^{A}\right)\end{array}$ & MGAT3_RAT & 62552 & 22 & 1 \\
\hline Golgi SNAP receptor complex member $2(B)$ & GOSR2_RAT & 24649 & 21 & 1 \\
\hline \multicolumn{5}{|l|}{ Nucleus } \\
\hline Vimentin $(A, B, C)$ & VIME_RAT & 53757 & 942 & 16 \\
\hline
\end{tabular}




\begin{tabular}{|c|c|c|c|c|}
\hline Proteins & Uniprot ID & Mass, Da & Score & Peptides \\
\hline Alpha-actinin-4 $(A, B, C)$ & ACTN4_RAT & 105306 & 319 & 18 \\
\hline Keratin, type I cytoskeletal $13(A, C)$ & K1C13_RAT & 48098 & 208 & 9 \\
\hline Lamin-B1 $\left({ }^{A}\right)$ & LMNB1_RAT & 66794 & 126 & 7 \\
\hline Caveolin-2 $(B)$ & CAV2_RAT & 18482 & 124 & 1 \\
\hline Histone H2A type 1-C $\left({ }^{A}\right)$ & H2A1C_RAT & 14097 & 123 & 2 \\
\hline Cullin-associated NEDD8-dissociated protein $2\left({ }^{A}\right)$ & CAND2_RAT & 141238 & 117 & 4 \\
\hline $60 \mathrm{~S}$ ribosomal protein $\mathrm{L} 23 \mathrm{a}(A, C)$ & RL23A_RAT & 17684 & 104 & 1 \\
\hline Homeobox protein Nkx-6.1 ( $A, B, C)$ & NKX61_RAT & 37723 & 89 & 1 \\
\hline Cyclin-dependent kinase 7 (Fragment) $(A)$ & CDK7_RAT & 37402 & 59 & 2 \\
\hline DNA-directed RNA polymerase I subunit RPA1 $(A, B, C)$ & RPA1_RAT & 196235 & 54 & 3 \\
\hline Centrosomal protein of $57 \mathrm{kDa}(A, C)$ & CEP57_RAT & 57404 & 49 & 4 \\
\hline Heterogeneous nuclear ribonucleoproteins A2/B1 ( $\left.{ }^{A}\right)$ & ROA2_RAT & 37512 & 49 & 1 \\
\hline Serine/threonine-protein kinase TNNI3K $(A, B)$ & TNI3K_RAT & 93985 & 44 & 1 \\
\hline Mitotic spindle assembly checkpoint protein MAD2B $(A, B)$ & MD2L2_RAT & 24615 & 39 & 1 \\
\hline Speckle targeted PIP5K1A-regulated polyA polymerase $\left({ }^{A}\right)$ & STPAP_RAT & 95516 & 38 & 2 \\
\hline Myc-induced nuclear antigen $\left({ }^{A}\right)$ & MINA_RAT & 53638 & 37 & 2 \\
\hline DNA mismatch repair protein Msh2 $\left({ }^{A}\right)$ & MSH2_RAT & 104704 & 37 & 5 \\
\hline Snurportin-1 $\left({ }^{A}\right)$ & SPN1_RAT & 41337 & 37 & 1 \\
\hline Transcription initiation factor TFIID subunit $6\left({ }^{A}\right)$ & TAF6_RAT & 73295 & 36 & 1 \\
\hline Ras association domain-containing protein $2(B)$ & RASF2_RAT & 38168 & 36 & 1 \\
\hline $60 \mathrm{~S}$ ribosomal protein L11 $\left({ }^{A}\right)$ & RL11_RAT & 20468 & 36 & 1 \\
\hline Serine/threonine-protein kinase MAK $(A, C)$ & MAK_RAT & 70280 & 35 & 1 \\
\hline Tyrosine-protein kinase Fer (Fragment) $\left({ }^{A}\right)$ & FER_RAT & 37479 & 35 & 2 \\
\hline Coiled-coil and C2 domain-containing protein 1B $\left({ }^{A}\right)$ & C2D1B_RAT & 93818 & 34 & 3 \\
\hline Splicing regulatory glutamine/lysine-rich protein $1(C)$ & SREK1_RAT & 56930 & 34 & 3 \\
\hline Zinc finger protein $57(A)$ & ZFP57_RAT & 47584 & 34 & 2 \\
\hline UPF0027 protein C22orf28 homolog $\left({ }^{A}\right)$ & CV028_RAT & 55727 & 33 & 1 \\
\hline Scaffold attachment factor $\mathrm{B} 1(A, B, C)$ & SAFB1_RAT & 104960 & 33 & 4 \\
\hline Transmembrane protein $109(A, B)$ & TM109_RAT & 26282 & 33 & 2 \\
\hline DNA topoisomerase $1(A, C)$ & TOP1_RAT & 91159 & 32 & 3 \\
\hline Hypoxia-inducible factor 3-alpha $\left({ }^{A}\right)$ & HIF3A_RAT & 73470 & 32 & 1 \\
\hline Nucleoporin GLE1 $\left({ }^{A}\right)$ & GLE1_RAT & 79955 & 31 & 4 \\
\hline Double-stranded RNA-specific editase $1\left({ }^{A}\right)$ & RED1_RAT & 78218 & 31 & 2 \\
\hline Doublesex- and mab-3-related transcription factor $\mathrm{C} 1\left({ }^{A}\right)$ & DMRTC_RAT & 24055 & 31 & 2 \\
\hline Origin recognition complex subunit $1(C)$ & ORC1_RAT & 96840 & 30 & 2 \\
\hline $5^{\prime}$-AMP-activated protein kinase subunit gamma-1 $\left({ }^{A}\right)$ & AAKG1_RAT & 37534 & 30 & 1 \\
\hline
\end{tabular}




\begin{tabular}{|c|c|c|c|c|}
\hline Proteins & Uniprot ID & Mass, Da & Score & Peptides \\
\hline Transforming growth factor beta regulator $1(A, C)$ & TBRG1_RAT & 45384 & 30 & 2 \\
\hline $\begin{array}{l}\text { High mobility group nucleosome-binding domain-containing } \\
\text { protein } 3\left({ }^{C}\right)\end{array}$ & HMGN3_RAT & 10176 & 30 & 1 \\
\hline Histone acetyltransferase MYST2 $(C)$ & MYST2_RAT & 71154 & 30 & 2 \\
\hline Zinc finger and BTB domain-containing protein $44(A, B)$ & ZBT44_RAT & 50987 & 30 & 3 \\
\hline DNA (cytosine-5)-methyltransferase $1(A, B)$ & DNMT1_RAT & 185054 & 30 & 5 \\
\hline $\begin{array}{l}\text { Nasal embryonic luteinizing hormone-releasing hormone } \\
\text { factor }\left({ }^{A}\right)\end{array}$ & NELF_RAT & 60701 & 30 & 4 \\
\hline Zinc finger and BTB domain-containing protein $24\left({ }^{A}\right)$ & ZBT24_RAT & 79355 & 29 & 3 \\
\hline Nuclear pore complex protein Nup155 $(A, B)$ & NU155_RAT & 156387 & 29 & 2 \\
\hline Period circadian protein homolog $2\left({ }^{B}\right)$ & PER2_RAT & 137539 & 28 & 2 \\
\hline Far upstream element-binding protein $2(A, B)$ & FUBP2_RAT & 74466 & 28 & 1 \\
\hline Paired box protein Pax-8 $\left({ }^{A}\right)$ & PAX8_RAT & 49118 & 28 & 1 \\
\hline Coiled-coil domain-containing protein $55(C)$ & CCD55_RAT & 64370 & 28 & 2 \\
\hline PIN2/TERF1-interacting telomerase inhibitor $1\left({ }^{A}\right)$ & PINX1_RAT & 36916 & 28 & 2 \\
\hline Coiled-coil domain-containing protein KIAA1826 homolog $\left(A_{\text {) }}\right.$ & K1826_RAT & 41264 & 28 & 1 \\
\hline Probable ATP-dependent RNA helicase DDX46 $(A, C)$ & DDX46_RAT & 117826 & 28 & 6 \\
\hline Lethal(3)malignant brain tumor-like protein $2\left({ }^{A}\right)$ & LMBL2_RAT & 80057 & 28 & 1 \\
\hline DNA-directed RNA polymerase III subunit RPC3 $\left({ }^{A}\right)$ & RPC3_RAT & 60903 & 27 & 2 \\
\hline DNA polymerase delta catalytic subunit $\left({ }^{A}\right)$ & DPOD1_RAT & 124948 & 27 & 5 \\
\hline Nuclear pore complex protein Nup54 $(A, C)$ & NUP54_RAT & 55825 & 27 & 1 \\
\hline ATP-dependent RNA helicase DDX39 $\left({ }^{A}\right)$ & DDX39_RAT & 49591 & 27 & 4 \\
\hline Histone deacetylase $4(A, C)$ & HDAC4_RAT & 119377 & 27 & 3 \\
\hline DNA topoisomerase 2-alpha $\left({ }^{A}\right)$ & TOP2A_RAT & 173853 & 27 & 6 \\
\hline PDZ domain-containing protein $2(A, C)$ & PDZD2_RAT & 296389 & 27 & 4 \\
\hline Coiled-coil domain-containing protein $104\left({ }^{A}\right)$ & CC104_RAT & 39736 & 27 & 2 \\
\hline Neurofibromin $(C)$ & NF1_RAT & 320473 & 27 & 1 \\
\hline Forkhead box protein $\mathrm{J} 1(C)$ & FOXJ1_RAT & 45994 & 27 & 2 \\
\hline Origin recognition complex subunit $2\left({ }^{A}\right)$ & ORC2_RAT & 66094 & 27 & 3 \\
\hline Transcriptional adapter 2-alpha ( $A, B$ ) & TAD2A_RAT & 52107 & 27 & 2 \\
\hline Telomerase protein component $1(A, B, C)$ & TEP1_RAT & 295173 & 26 & 5 \\
\hline Transcription factor EC ( $A, C)$ & TFEC_RAT & 35495 & 26 & 2 \\
\hline SAP domain-containing ribonucleoprotein $\left({ }^{A}\right)$ & SARNP_RAT & 23647 & 26 & 2 \\
\hline Transcription elongation factor A protein-like $8\left({ }^{A}\right)$ & TCAL8_RAT & 13553 & 26 & 1 \\
\hline Protein AATF $\left({ }^{A}\right)$ & AATF_RAT & 59461 & 26 & 2 \\
\hline DNA-directed RNA polymerase I subunit RPA2 $\left({ }^{A}\right)$ & RPA2_RAT & 129462 & 26 & 2 \\
\hline Zinc finger $\mathrm{CCCH}$ domain-containing protein $18(C)$ & ZCH18_RAT & 105702 & 26 & 2 \\
\hline
\end{tabular}




\begin{tabular}{|c|c|c|c|c|}
\hline Proteins & Uniprot ID & Mass, Da & Score & Peptides \\
\hline Transcription factor AP-2-alpha $(A, C)$ & AP2A_RAT & 48316 & 26 & 3 \\
\hline Neuronal PAS domain-containing protein $4(C)$ & NPAS4_RAT & 88004 & 26 & 1 \\
\hline Clusterin-associated protein $1\left({ }^{B}\right)$ & CLUA1_RAT & 46543 & 26 & 2 \\
\hline Apolipoprotein A-IV $\left({ }^{A}\right)$ & APOA4_RAT & 44429 & 25 & 1 \\
\hline $60 \mathrm{~S}$ ribosomal protein $\mathrm{L} 3(A), B$ ) & RL3_RAT & 46392 & 25 & 4 \\
\hline 40S ribosomal protein $\mathrm{S} 13\left({ }^{A}\right)$ & RS13_RAT & 17212 & 25 & 2 \\
\hline Phosphatase and actin regulator $3(A, B)$ & PHAR3_RAT & 58596 & 25 & 2 \\
\hline Histone H3.3 $\left({ }^{A}\right)$ & H33_RAT & 15376 & 25 & 2 \\
\hline SKI family transcriptional corepressor $1\left({ }^{A}\right)$ & SKOR1_RAT & 101312 & 25 & 3 \\
\hline Protein GRINL1A $(A, B)$ & GRL1A_RAT & 41305 & 25 & 1 \\
\hline Cell growth-regulating nucleolar protein $(A, C)$ & LYAR_RAT & 44110 & 25 & 2 \\
\hline Pancreas/duodenum homeobox protein $1(C)$ & PDX1_RAT & 30983 & 25 & 1 \\
\hline DNA repair protein RAD50 $(A, C)$ & RAD50_RAT & 154772 & 25 & 15 \\
\hline RAC-gamma serine/threonine-protein kinase $(B)$ & AKT3_RAT & 56217 & 25 & 2 \\
\hline Leucine-rich repeat flightless-interacting protein $1\left({ }^{C}\right)$ & LRRF1_RAT & 80484 & 25 & 2 \\
\hline Something about silencing protein $10(C)$ & SAS10_RAT & 53949 & 24 & 1 \\
\hline Structural maintenance of chromosomes protein $3(A, B, C)$ & SMC3_RAT & 138761 & 24 & 4 \\
\hline MACRO domain-containing protein 1 (Fragment) $\left({ }^{C}\right)$ & MACD1_RAT & 29081 & 24 & 2 \\
\hline ZW10 interactor $(C)$ & ZWINT_RAT & 30295 & 24 & 3 \\
\hline Protein Dom3Z $(A, C)$ & DOM3Z_RAT & 45784 & 24 & 2 \\
\hline $\operatorname{Kazrin}(C)$ & KAZRN_RAT & 87433 & 24 & 3 \\
\hline General transcription factor $3 \mathrm{C}$ polypeptide $1(A, B, C)$ & TF3C1_RAT & 245004 & 24 & 3 \\
\hline Suppression of tumorigenicity 18 protein $\left({ }^{A}\right)$ & ST18_RAT & 115074 & 24 & 2 \\
\hline Myocyte-specific enhancer factor 2A $\left({ }^{A}\right)$ & MEF2A_RAT & 53391 & 24 & 2 \\
\hline Homeobox protein MOX-2 $\left({ }^{A}\right)$ & MEOX2_RAT & 33869 & 24 & 1 \\
\hline Ubiquitin carboxyl-terminal hydrolase $16\left({ }^{A}\right)$ & UBP16_RAT & 95242 & 24 & 3 \\
\hline Sentrin-specific protease $2\left({ }^{A}\right)$ & SENP2_RAT & 67837 & 24 & 1 \\
\hline Far upstream element-binding protein $1(A, B)$ & FUBP1_RAT & 67326 & 24 & 3 \\
\hline Hepatoma-derived growth factor-related protein $2\left({ }^{A}\right)$ & HDGR2_RAT & 74088 & 24 & 1 \\
\hline $\begin{array}{l}\text { 1-phosphatidylinositol-4,5-bisphosphate phosphodiesterase } \\
\text { beta-1 }(A)\end{array}$ & PLCB1_RAT & 139113 & 24 & 1 \\
\hline Selenocysteine insertion sequence-binding protein $2(A, B, C)$ & SEBP2_RAT & 94154 & 24 & 5 \\
\hline Protein salvador homolog $1\left({ }^{B}\right)$ & SAV1_RAT & 45133 & 24 & 3 \\
\hline Structural maintenance of chromosomes protein $1 \mathrm{~A}\left({ }^{A}\right)$ & SMC1A_RAT & 143743 & 23 & 5 \\
\hline DNA-binding protein SMUBP-2 $(A)$ & SMBP2_RAT & 109400 & 23 & 3 \\
\hline Myocyte-specific enhancer factor 2D $(A, B)$ & MEF2D_RAT & 54563 & 23 & 3 \\
\hline
\end{tabular}




\begin{tabular}{|c|c|c|c|c|}
\hline Proteins & Uniprot ID & Mass, Da & Score & Peptides \\
\hline Nuclear pore membrane glycoprotein $210(A, B)$ & PO210_RAT & 204943 & 23 & 2 \\
\hline Myb-binding protein 1A $(A)$ & MBB1A_RAT & 153046 & 23 & 4 \\
\hline Fidgetin-like protein $1\left({ }^{A}\right)$ & FIGL1_RAT & 74891 & 23 & 1 \\
\hline Smad nuclear interacting protein $1\left({ }^{A}\right)$ & SNIP1_RAT & 44953 & 23 & 1 \\
\hline Aryl hydrocarbon receptor nuclear translocator $2\left({ }^{A}\right)$ & ARNT2_RAT & 78536 & 23 & 1 \\
\hline $\mathrm{H} / \mathrm{ACA}$ ribonucleoprotein complex subunit $1(A, B)$ & GAR1_RAT & 23167 & 23 & 1 \\
\hline Putative rRNA methyltransferase $3(A, B, C)$ & RRMJ3_RAT & 95165 & 23 & 2 \\
\hline REST corepressor $2\left({ }^{C}\right)$ & RCOR2_RAT & 58116 & 23 & 1 \\
\hline PR domain zinc finger protein $2(C)$ & PRDM2_RAT & 189890 & 23 & 2 \\
\hline MutS protein homolog $5(B, C)$ & MSH5_RAT & 93362 & 23 & 2 \\
\hline E3 SUMO-protein ligase PIAS3 $(C)$ & PIAS3_RAT & 69289 & 23 & 1 \\
\hline Transcription factor IIIB $50 \mathrm{kDa}$ subunit $(C)$ & BRF2_RAT & 47421 & 22 & 2 \\
\hline 6-phosphofructo-2-kinase/fructose-2,6-biphosphatase $3\left({ }^{C}\right)$ & F263_RAT & 64491 & 22 & 1 \\
\hline Vitamin D3 receptor $\left({ }^{B}\right)$ & VDR_RAT & 48467 & 22 & 2 \\
\hline Meiosis-specific nuclear structural protein $1(A, B)$ & MNS1_RAT & 61316 & 22 & 5 \\
\hline Cell division cycle-associated protein $7\left({ }^{A}\right)$ & CDCA7_RAT & 43909 & 22 & 2 \\
\hline Kinesin-like protein $\operatorname{KIF} 22(A, C)$ & KIF22_RAT & 73239 & 22 & 5 \\
\hline Protein timeless homolog $\left({ }^{A}\right)$ & TIM_RAT & 139562 & 22 & 4 \\
\hline U11/U12 small nuclear ribonucleoprotein $35 \mathrm{kDa}$ protein $\left({ }^{A}\right)$ & U1SBP_RAT & 29186 & 22 & 2 \\
\hline Nuclear pore complex protein Nup85 $(A, B)$ & NUP85_RAT & 29186 & 22 & 2 \\
\hline Interferon-stimulated $20 \mathrm{kDa}$ exonuclease-like $2\left({ }^{A}\right)$ & I20L2_RAT & 41684 & 22 & 3 \\
\hline ATPase WRNIP1 $\left({ }^{A}\right)$ & WRIP1_RAT & 72687 & 22 & 2 \\
\hline Nucleolar RNA helicase $2\left({ }^{A}\right)$ & DDX21_RAT & 86540 & 22 & 4 \\
\hline Period circadian protein homolog $1(A, B)$ & PER1_RAT & 137562 & 22 & 2 \\
\hline U4/U6.U5 tri-snRNP-associated protein $1(A, B, C)$ & SNUT1_RAT & 91127 & 22 & 2 \\
\hline Intraflagellar transport protein 172 homolog $(C)$ & IF172_RAT & 199245 & 22 & 2 \\
\hline Serine/threonine-protein kinase PRP4 homolog $\left({ }^{A}\right)$ & PRP4B_RAT & 117335 & 22 & 3 \\
\hline CLK4-associating serine/arginine rich protein $(C)$ & CLASR_RAT & 76932 & 22 & 3 \\
\hline Nuclear pore complex protein Nup98-Nup96 $\left({ }^{A}\right)$ & NUP98_RAT & 198358 & 21 & 1 \\
\hline Nucleolar GTP-binding protein $1\left({ }^{A}\right)$ & NOG1_RAT & 74640 & 21 & 3 \\
\hline Protein SCAF8 $\left({ }^{A}\right)$ & SCAF8_RAT & 139874 & 21 & 2 \\
\hline Myogenin $(A, B, C)$ & MYOG_RAT & 33224 & 21 & 2 \\
\hline Ester hydrolase $\mathrm{C} 11$ orf54 homolog $(C)$ & CK054_RAT & 35427 & 21 & 2 \\
\hline Uncharacterized protein $\mathrm{C} 1$ orf103 homolog $(C)$ & CA103_RAT & 83074 & 21 & 4 \\
\hline Poly(ADP-ribose) glycohydrolase ( $A, B$ ) & PARG_RAT & 110417 & 21 & 1 \\
\hline Dual specificity protein kinase $\left.\mathrm{CLK} 3{ }_{(}{ }^{C}\right)$ & CLK3_RAT & 59247 & 21 & 2 \\
\hline
\end{tabular}




\begin{tabular}{lllll}
\hline Proteins & Uniprot ID & Mass, Da & Score & Peptides \\
\hline Scm-like with four MBT domains protein $1(A, B, C)$ & SMBT1_RAT & 98984 & 21 & 1 \\
Chromodomain-helicase-DNA-binding protein $8(A, B, C)$ & CHD8_RAT & 292449 & 21 & 1 \\
Digestive organ expansion factor homolog $(C)$ & DEF_RAT & 88169 & 21 & 2 \\
Uncharacterized protein C12orf32 homolog $(C)$ & CL032_RAT & 27281 & 21 & 1 \\
Regulator of G-protein signaling 14 $(C)$ & RGS14_RAT & 59968 & 21 & 1 \\
Zinc finger CCHC-type and RNA-binding motif-containing & & & & \\
protein 1 $(C)$ & ZCRB1_RAT & 24758 & 21 & 2 \\
Spliceosome RNA helicase Bat1 $(B)$ & UAP56_RAT & 49460 & 21 & 1 \\
E3 SUMO-protein ligase PIAS2 $(B)$ & PIAS2_RAT & 64303 & 21 & 1 \\
\hline
\end{tabular}

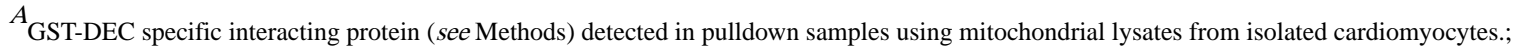
$B$ $B$ same as in A but using whole-cell cardiomyocyte lysates;

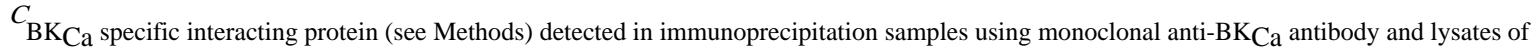
Percoll purified mitochondria from left ventricle. 